\title{
The role of corporate governance in accounting discretion under IFRS: Goodwill impairment in Australia
}

Please cite this article as: Humayun Kabir, Asheq Rahman, The role of corporate governance in accounting discretion under IFRS: Goodwill impairment in australia, Journal of Contemporary Accounting \& Economics (2016), http://dx.doi.org/doi: 10.1016/j.jcae.2016.10.001.

\section{Humayun Kabir*}

Department of Accounting, Faculty of Business, Economics and Law, Auckland University of

Technology,

Auckland 1142, New Zealand

E-mail: humayun.kabir@aut.ac.nz

Asheq Rahman

Department of Accounting, Faculty of Business, Economics and Law, Auckland University of Technology, Auckland 1142, New Zealand

E-mail: asheq.rahman@aut.ac.nz

*Corresponding author: Private Bag 92006, AUT University, Auckland 1142, New Zealand E-mail address: $\underline{\text { humayun.kabir@aut.ac.nz }}$

We appreciate the constructive comments of the editor and the anonymous reviewer. We also thank the participants at 2015 AFAANZ Conference, Auckland Region Accounting conference 2014 and Auckland University of Technology seminar for their comments on earlier versions of this paper. 


\title{
The role of corporate governance in accounting discretion under IFRS: Goodwill impairment in Australia
}

\begin{abstract}
A major concern with the adoption of International Financial Reporting Standards (IFRS) is the accounting discretion allowed under the IFRS, and its potential opportunistic use by managers. We examine the role of corporate governance in the accounting discretion inherent in goodwill impairment decisions under the IFRS. More specifically, we investigate whether, in Australia, stronger governance strengthens associations between economic factors and goodwill impairment loss but weakens associations between contracting incentives and goodwill impairment loss. Using data from 2007 to 2012, we find evidence consistent with the notion that stronger governance enhances the associations between economic factors and goodwill impairment loss. However, we find that strong governance cannot completely eliminate the opportunistic use of discretion in an impairment decision, especially when pre-impairment income is negative, and when the impairment occurs in the first year of a CEO's tenure. Our results are robust with regards to alternative measures of the dependent variable, firm performance variables, and the governance variable, even after controlling for potential self-selection biases.
\end{abstract}

JEL Classification: G34, M41

Keywords: Goodwill impairment; IFRS; Corporate governance; Accounting discretion; Australia

\section{Introduction}

Preparers and users of financial reports and enforcers of financial reporting regulations have a major concern with the International Financial Reporting Standards (IFRS): the significant level of estimation and judgment allowed, and its potential to be used opportunistically in the absence of sound corporate governance (FEE, 2001, 2002; Pope and McLeay, 2011; US SEC, 2000). One area of accounting that allows a great deal of managerial discretion under the IFRS and has attracted the attention of academics and practitioners for its complexity, is goodwill impairment (Carlin and Finch, 2008; KPMG, 2014). A complex discretionary accounting scenario, such as goodwill impairment, provides an ideal setting for testing the role of corporate governance in accounting discretion in general, and under IFRS in particular. Therefore, we investigate the role of corporate governance in goodwill impairment.

To conduct our investigation, we choose the Australian setting. With the shift from preIFRS Australian GAAP to IFRS in 2005, the Australian goodwill accounting standard changed from 
the annual amortisation regime to that of impairment. Prior to the adoption of IFRS in Australia, goodwill was amortised annually over a maximum period of 20 years (AASB, 1996, para 5.2). In contrast, AASB 136, the Australian accounting standard that deals with impairment of assets, requires goodwill to be tested annually for impairment, and precludes annual amortisation (AASB, 2014b). Conceptually it is sound, because it relates accounting adjustments to the economic reality of economic entities. However, it has raised concerns about whether annual impairments relate to the economic reality of the entity to which the goodwill belongs (KPMG, 2014). These concerns are particularly important in countries such as Australia, which previously had clearly stated amortisation regimes instead of the impairment regime (AASB, 1996).

Australia has upward revaluation regimes for long-term assets, but not for goodwill ${ }^{1}$. An upward and downward revaluation regime allows for the recognition of both upside gains and downside risks. Further, in contrast with other assets for which AASB 136 requires the reversal of impairment loss if certain conditions are met, the standard prohibits the reversal of goodwill impairment loss (AASB, 2014b, para $114 \& 124$ ). In the absence of the ability to recognise upward gain and reverse goodwill impairment loss, and in the presence of contracting incentives, firms can be reluctant to recognise downside risks. In such settings, corporate governance could perform an important monitoring role to ensure that the goodwill impairment regime reflects the economic reality of the entity. ${ }^{2}$

Accounting for goodwill impairment under AASB 136 requires complex subjective judgments and estimates. Preparers, analysts and regulators consider goodwill impairment testing to be "a critical judgment and a key area of estimation uncertainty in preparing financial statements" (KPMG, 2014, p. 2). In the presence of variations in governance qualities, these

\footnotetext{
${ }^{1}$ For example, AASB 116 Property, Plant and Equipment and AASB 138 Intangible Assets allow both upward and downward revaluation of property, plant and equipment, and intangible assets, respectively (AASB, 2014a, 2014c).

2 The Australian Securities Exchange (ASX) Corporate Governance Principles and Recommendations posit that the board of directors has the ultimate responsibility to ensure the integrity of financial reporting (ASX Corporate Governance Council, 2007, p. 26).
} 
judgments and estimates can be used for two opposing ends. On the one hand, managers may use this flexibility to represent the underlying economic reality and to signal private information about the entity. On the other hand, they may use such flexibility opportunistically.

Further, goodwill is a material item in the statement of financial position. For example, the median goodwill (divided by total assets) in our sample is $15.85 \%$. To put this figure into perspective, the median net income (deflated by total assets) is $4.32 \%$. Thus, goodwill impairment can have a material impact on the earnings of the company. Since corporate governance is entrusted with monitoring the financial reporting of the company (ASX Corporate Governance Council, 2007, p. 26), the goodwill impairment test allows much flexibility to management, and since goodwill impairment loss impacts the company's net income significantly, it is important to understand the influence of corporate governance on goodwill impairment decisions.

While Chalmers et al. (2011) find that goodwill impairment loss better reflects economic reality than goodwill amortisation does in Australia, we do not know whether this finding holds across all firms irrespective of the strength of corporate governance. Therefore, we examine whether the associations between goodwill impairment loss and the proxies for economic reality are contingent upon the strength of the firm's corporate governance. This examination is important, as it may provide potentially important insights for "regulators in countries preparing to change their financial reporting regime", and for regulators in Australia and elsewhere “considering ways of improving the implementation of IFRS" (Pope and McLeay, 2011, p. 241).

Prior accounting studies examined the associations between corporate governance and the broad proxies of financial reporting quality such as fraudulent financial reporting, voluntary disclosure, accrual quality, earnings management and conservatism (Ahmed and Duellman, 2007; Cheng and Courtenay, 2006; Dechow et al., 1996; Eng and Mak, 2003; Lee et al., 2003; Peasnell et al., 2005). In contrast, this study examines the role of corporate governance in the context of the 
implementation of a particular IFRS, as studies on the role of corporate governance in accounting decisions under IFRS are relatively sparse. ${ }^{3}$

Monitoring the implementation of a particular IFRS requires the monitors (e.g., the board, the audit committee and the auditor) to understand it and to monitor its implementation as per the guidance in that IFRS. For example, monitoring the goodwill impairment decisions of management would require the monitors to understand the goodwill impairment regime, monitor the potential indicators of impairment, and assess whether the impairment decision (i.e., impair or not impair) and the magnitude of impairment loss are consistent with the indicators. Therefore, it is not clear whether prior evidence on the impact of corporate governance on financial reporting quality can be generalised to the goodwill impairment setting. By investigating the role of corporate governance in the context of goodwill impairment, this paper extends that literature.

We find that stronger governance strengthens the associations between economic factors (e.g., the change in cash flow, the book-to-market ratio and the Gross Domestic Product (GDP) growth rate) and goodwill impairment loss. Further analysis shows that all six governance attributes - board independence, audit committee independence, Big 4 auditor, audit committee expertise, audit committee meeting frequency, and Chief Executive Officer (CEO) separation increase the likelihood of goodwill impairment loss when economic indicators of goodwill impairment are present. We, however, find that only three governance attributes - Big 4 auditor, audit committee expertise, and separation between CEO and the board chair - enhance the associations between economic factors and the magnitude of impairment loss. However, we also find that, irrespective of the strength of corporate governance, the likelihood and the magnitude of goodwill impairment loss are higher when pre-impairment income is negative, and in the first year of the CEO's tenure. Further investigation provides preliminary evidence that goodwill

\footnotetext{
${ }^{3}$ One exception is Duh et al. (2009) who examine whether corporate governance mitigates the opportunistic use of the reversal of impairment loss. In contrast, we examine goodwill impairment loss, which is not allowed to be reversed.
} 
impairment loss is used by some firms as a big bath tool. Thus, governance cannot completely eliminate the opportunistic use of the accounting discretion. Finally, we find that goodwill impairment loss in year t- 1 is likely to be followed by the same in year $t$. Our results are robust to alternative measures of the dependent variable (i.e., binary vs. continuous variable), firm performance variables, and the governance variable, and hold after controlling for potential selfselection bias.

Australia is a common-law country having an accounting environment similar to those of other common-law countries such as the United States, the United Kingdom, Canada and New Zealand ${ }^{4}$. Therefore, evidence on the role of corporate governance in goodwill impairment from Australia is generalisable for other common-law countries and relevant for countries that are preparing to switch to IFRS.

This paper makes three contributions to both the goodwill impairment and corporate governance literature. First, while prior studies (Beatty and Weber, 2006; Chalmers et al., 2011; Godfrey and Koh, 2009) report that goodwill impairment loss is associated with proxies of economic realities, we document that the associations between goodwill impairment loss and economic indicators of goodwill impairment are more likely to be observed in firms with stronger corporate governance than for those with weaker governance. Second, the corporate governance and financial reporting literature shows that corporate governance improves financial reporting quality (Brown et al., 2011). We document that while stronger corporate governance improves the associations between economic factors and goodwill impairment loss, it does not eliminate the opportunistic use of accounting discretion involved in goodwill impairment decisions. Third, while Duh et al. (2009) examine whether corporate governance mitigates the opportunistic use of the reversal of impairment loss, this paper extends this literature by examining the role of corporate governance in a new setting - goodwill impairment - that is fundamentally different from the impairment loss of other long-lived assets that must be reversed under certain

${ }^{4}$ For example, La Porta et al. (1998, Tables 2 and 5) report similar anti-director rights, rule of law and efficiency of the judicial system in Australia and other common-law countries. 
conditions (AASB, 2014b, para 114). In contrast, AASB 136 does not permit the reversal of goodwill impairment loss (AASB, 2014b, para 124).

The remainder of the paper is organised in the following manner: section 2 discusses the main provisions regarding goodwill impairment testing under AASB 136, and section 3 provides a brief survey of the goodwill impairment and corporate governance literature, and develops the hypotheses. Section 4 defines the variables and section 5 discusses the empirical models. Section 6 discusses data and sample, and section 7 presents the findings. The final section draws the conclusions.

\section{Goodwill impairment under AASB 136 and accounting discretion}

The shift from amortisation to impairment for goodwill is a major conceptual change in accounting for goodwill. While it allows for better recognition of the economic reality of groups of economic entities, it opens the door for discretion that can be opportunistically used by the managers. The chances of opportunistic behaviour can be exacerbated by the requirement that goodwill can only be impaired and not revalued upwards.

AASB 136 (hereinafter 'the standard') specifies the recognition, measurement and disclosure of impairment loss. The standard requires an impairment loss to be recognised when the carrying amount of an asset exceeds its recoverable amount (AASB, 2014b, para 59). The recoverable amount of an asset is the higher of its fair value less costs of disposal, and its valuein-use (AASB, 2014b, para 6).

The standard requires testing for goodwill impairment annually and, also, when there is an indication that goodwill has been impaired (AASB, 2014b, para 9 and 10). For the purpose of impairment testing, goodwill is to be allocated to cash generating units (CGUs), or groups of CGUs, that are expected to benefit from the synergies of the combination (AASB, 2014b, para 80). AASB 
136.6 defines a CGU as "the smallest identifiable group of assets that generates cash inflows that are largely independent of the cash inflows from other assets or groups of assets" (AASB 2014b).

A CGU to which goodwill has been allocated is required to be tested for impairment annually, and whenever there is an indication that the unit may be impaired, by comparing the carrying amount of the CGU, including the allocated goodwill, with the recoverable amount of the unit (AASB, 2014b, para 90). If the carrying amount of the CGU exceeds its recoverable amount, an impairment loss is required to be recognised for the unit (AASB, 2014b, para 104). The impairment loss is to be allocated to reduce (a) first, the carrying amount of any allocated goodwill; and (b) then, the carrying amounts of other assets of the unit on a pro rata basis (AASB, 2014b, para 104).

Thus, the goodwill-impairment testing process requires management to exercise discretion at three stages: the number of CGUs to which goodwill is to be allocated, the amount of goodwill to be allocated to each CGU, and determination of the recoverable amount of the CGU. The accounting discretion provides an opportunity for managers to reveal their private information about the future earnings and cash flow prospects of the company (Li et al., 2010). The discretion also provides opportunities for the manipulation of goodwill impairment loss.

While AASB 136.80 provides some guidance on the choice of units for allocating goodwill for impairment testing 5 , management may manipulate the number of CGUs to which goodwill is allocated (Carlin et al., 2007). Further, management can manipulate goodwill impairment loss by estimating the amount of goodwill to be allocated to the CGUs. For example, management may avoid reporting impairment loss by allocating more goodwill to profitable CGUs.

Given that most used fixed assets and intangibles lack active markets, entities are less likely to estimate recoverable amounts using the fair value approach. Carlin and Finch (2008)

\footnotetext{
${ }^{5}$ AASB (2014b, para 80) provides three guidelines for the choice of CGUs or groups of CGUs to which goodwill is to be allocated. Such units shall (a) be expected to benefit from the synergies of the business combination, (b) represent the lowest level within the entity at which the goodwill is monitored for internal management purposes, and (c) not be larger than an operating segment, as defined in AASB 8 Operating Segments, before aggregation.
} 
report that 157 Australian companies, out of their 200 sample companies, used value-in-use to estimate the recoverable amount of CGUs in $2006 .{ }^{6}$ The estimation of value-in-use of an asset involves two steps: (a) estimating the future cash inflows and outflows resulting from its continuing use and ultimate disposal, and (b) applying the appropriate discount rate to those cash flows (AASB, 2014b, para 31). Estimates of future cash flows are to be based on reasonable and supportable assumptions that represent management's best estimate of the range of economic conditions that will exist over the remaining useful life of the asset, and the most recent financial budgets/forecasts approved by management (AASB, 2014b, para 33). Therefore, the estimates involved in estimating the value-in-use of the CGU are essentially forward-looking and provide ample opportunities for managers to manipulate cash flow projections and the goodwill impairment loss. Further, the discount rate used to discount future cash flows can be chosen so as not to result in goodwill impairment loss (Carlin and Finch, 2009). In cases where the recoverable amount of the CGU is estimated using the fair value less the cost of disposal, the fair value estimate belongs to a Level III estimate, as many assets, most notably the intangible assets, lack active markets. The upshot is, regardless of the basis used to determine the recoverable amount of the CGU, goodwill impairment accounting requires managers to make unverifiable estimates and complex judgments.

The standard expects managers to use goodwill impairment estimates to signal private information to investors about the future profitability of the assets of the company. However, the requirement to use the above estimates and judgments under AASB 136 creates opportunities for managers to manipulate any goodwill impairment loss to meet managerial contracting goals. While Chalmers et al. (2011) document that goodwill impairment loss under AASB 136 reflects the underlying economic attributes of goodwill, the United States studies (Beatty and Weber,

\footnotetext{
${ }^{6}$ Seventeen of their 200 sample companies used the fair value approach, seven used both fair value and value-in-use, and the remaining nineteen did not disclose the estimation approach (Carlin and Finch, 2008).
} 
2006; Godfrey and Koh, 2009) find that goodwill impairment loss is associated with both economic realities and reporting incentives.

However, these studies do not examine whether goodwill impairment loss is associated with economic reality, irrespective of the strength of corporate governance. The role of corporate governance is important because, as mentioned above, the goodwill impairment regime permits much managerial discretion, which managers may use opportunistically in the absence of strong corporate governance. Therefore, this paper examines the role of corporate governance in managerial accounting choice when discretion is permitted.

\section{Related research and hypotheses}

There is a substantial literature on goodwill impairment in the US. This literature finds that goodwill impairment loss is driven by economic reality as well as managerial opportunism. For example, goodwill impairment loss is observed to be associated with contemporaneous annual returns (Chen et al., 2004), future decline in profitability (Li et al., 2010), investment opportunities, return on assets, size and leverage (Godfrey and Koh, 2009), as well as with debt covenant, bonus plan and equity market considerations, CEO tenure and growth options (Beatty and Weber, 2006).

Henning et al. (2004), on the other hand, find that, judged by their models of estimated goodwill impairments, the magnitude of actual impairments during the pre-SFAS 142 era was not inflated. However, they find that a disproportionately high percentage of firms with weak performance recognise impairments upon adopting SFAS 142, thus indicating that SFAS 142 might have triggered recognition of impairments by reducing the flexibility previously afforded by pre-SFAS 142 GAAP. Ramanna and Watts (2010) report that goodwill non-impairment is associated with debt covenants, CEO compensation and CEO tenure in the United States, and find no evidence that goodwill non-impairment is associated with management's private information on positive future prospects of the company. 
Non-United States studies, albeit few in number, also seem to find support for both the economic factors and the managerial opportunism hypotheses. Chalmers et al. (2011) find that goodwill impairment loss reported by Australian companies is associated with investment opportunities. Carlin and Finch (2009), on the other hand, argue that management chooses the discount rate for goodwill impairment testing opportunistically, such that they do not have to recognise any impairment.

On the other hand, an extensive literature examines the association between corporate governance and financial reporting outcomes (Brown et al., 2011). The financial reporting outcomes examined include disclosure (Beekes and Brown, 2006; Cerbioni and Parbonetti, 2007; Kent and Stewart, 2008), conservatism (Ahmed and Duellman, 2007; Kim et al., 2003), manipulation of research and development expenditure (Osma, 2008), earnings management (Bedard et al., 2004; Nelson et al., 2003; Peasnell et al., 2005; Xie et al., 2003), and fraud and financial restatements (Abbott et al., 2004; Sharma, 2004).

However, prior research does not examine the association between corporate governance and goodwill impairment loss. Given the concern arising out of the extensive use of managerial estimates and judgments in goodwill impairment decisions, it is important to investigate the role of corporate governance in these decisions. While prior research examines the association between governance and financial reporting outcomes, goodwill impairment is different from accounting outcomes (e.g., voluntary disclosure and conservatism) examined in the prior literature. For example, monitoring a goodwill impairment decision requires the monitors (e.g., the board, the audit committee and the auditor) to assess whether the impairment decision (i.e., impaired or not impaired) is in line with the relevant accounting standard (i.e., AASB 136). While reporting a higher magnitude of goodwill impairment loss would be construed as conservative accounting (an indicator of accounting quality), it would not necessarily be in accordance with the AASB 136. This standard requires the recording of goodwill impairment loss only when it is actually impaired. Thus, monitoring the goodwill impairment decision requires governance to monitor the indicators of impairment and unverifiable estimates (e.g., cash flow forecasts and 
discount rate) used in calculating goodwill impairment loss. Hence, it is not clear whether the evidence on the effectiveness of governance documented for various accounting outcomes in the prior literature extends equally well to goodwill impairment. By investigating the role of corporate governance in goodwill impairment, this paper seeks to extend this literature.

Regulators rely on the monitoring role of corporate governance, especially that of the board of directors and the independent auditor, to ensure the integrity of an entity's financial reporting (ASX Corporate Governance Council, 2007; Cadbury Report, 1992; National Commission on Fraudulent Financial Reporting, 1987). Consistent with the corporate governance regulatory literature, prior research indicates that sound corporate governance monitors the exercise of accounting discretion and improves financial reporting quality. For example, Klein (2002) documents that companies with a less independent audit committee have greater abnormal accruals. Similarly, Myers (2001) finds that audit committees appear to be more effective in reducing the size of restructuring and other discretionary charges when the audit committee has at least one member who has accounting or related financial expertise. Nelson et al. (2003) report results suggesting that auditors are less likely to waive earnings management attempts that increase current-year income, and more likely to waive attempts they view as immaterial. Becker et al. (1998) and Francis et al. (1999) document that clients of non-Big Six auditors report higher absolute discretionary accruals than do Big Six auditors.

If, as the regulatory and academic literature suggests, stronger governance monitors managers' use of accounting flexibility and improves accounting quality, it is also likely to ensure that the estimates and judgments inherent in testing goodwill for impairment are used appropriately. In other words, stronger corporate governance is likely to ensure that goodwill impairment loss is recorded when economic indicators of goodwill impairment exist. On the other hand, stronger corporate governance is likely to mitigate the opportunistic use of the estimates and judgments involved in goodwill impairment testing resulting from managers' contracting incentives. Thus, our hypotheses are as follows: 
H1. The association between economic factors and goodwill impairment loss is strengthened by stronger corporate governance.

H2. The association between contracting incentives and goodwill impairment loss is greater for firms with weaker governance than for those with stronger governance.

\section{Variables}

\subsection{Dependent variable}

This study uses two measures for dependent variable goodwill impairment: DIMPR $\mathrm{R}_{\mathrm{i}, \mathrm{t}}$ and $I_{M P R_{i, t}}$ DIMPR $\mathrm{R}_{\mathrm{i}, \mathrm{t}}$ is an indicator variable that takes a value of one if firm i reports goodwill impairment loss in year $\mathrm{t}$, and zero otherwise. On other hand, $\mathrm{IMPR}_{\mathrm{i}, \mathrm{t}}$ is measured as goodwill impairment loss of firm i in year $t$ divided by total assets at the end of year $\mathrm{t}-1$.

\subsection{Economic factors}

Following prior research, we include six economic factors: (a) sales growth $\left(\Delta \mathrm{SALES}_{\mathrm{i}, \mathrm{t}}\right)$ (Duh et al., 2009; Riedl, 2004), (b) change in operating cash flows over the year $\left(\Delta \mathrm{CFO}_{\mathrm{i}, \mathrm{t}}\right)(\mathrm{Riedl}$, 2004), (c) an indicator variable for pre-impairment earnings (DPREINC $C_{i, t}$ ) (Riedl, 2004), (d) change in industry median return on assets $\left(\Delta \mathrm{INDROA}_{k, t}\right)($ Riedl, 2004), (e) book-to-market ratio $\left(\mathrm{B} / \mathrm{M}_{\mathrm{i}, \mathrm{t}}\right.$ ) (Zhang and Zhang, 2007), and (f) lagged goodwill impairment loss (IMPR $\mathrm{R}_{\mathrm{i}, \mathrm{t}-\mathrm{1}}$ or DIMPR $\mathrm{i}, \mathrm{t}-$

1) (Elliott and Hanna, 1996). Since the sample firms experienced the global economic recession during the sample period, and economic downturn affects the prospect of furture cash flows to the firm, we also include a macro-economic variable: GDP growth rate (GDPR), as the seventh economic factor. 
Three firm-specific economic indicators, $\triangle \mathrm{SALES} \mathrm{S}_{\mathrm{i}, \mathrm{t}} \Delta \mathrm{CFO}_{\mathrm{i}, \mathrm{t}}$ and DPREINC $\mathrm{i}_{\mathrm{i}, \mathrm{t}}$ are included in the models. $\triangle \mathrm{SALES}_{\mathrm{i}, \mathrm{t}}$ and $\triangle \mathrm{CFO}_{\mathrm{i}, \mathrm{t}}$ capture changes in firm-level performance, and negative changes in performance may indicate financial troubles in the companies. Hence, these two variables are predicted to be negatively associated with goodwill impairment loss (Riedl, 2004).

DPREINC $_{\mathrm{i}, \mathrm{t}}$ takes a value of one if pre-impairment income is positive and zero otherwise. If goodwill impairment loss is recorded when earnings performance is poor, goodwill impairment loss would be negatively associated with DPREINC $\mathrm{C}_{\mathrm{i}, \mathrm{t}}$. But if managers smooth reported net income, they would report more goodwill impairment loss when DPREINC $t$ is positive. In that case, goodwill impairment loss would be associated with DPREINC $\mathrm{i}_{\mathrm{i}, \mathrm{t}}$ positively. Thus, we do not posit the direction of association between DPREINC $\mathrm{C}_{\mathrm{i}, \mathrm{t}}$ and goodwill impairment loss.

We include $\triangle \mathrm{INDROA}_{\mathrm{k}, \mathrm{t}}$ because it captures changes in industry-specific economic conditions, and firms in declining industries are more likely to experience goodwill impairment than those in other industries (Riedl, 2004). Thus, we expect a negative association between $\triangle \mathrm{INDROA}_{\mathrm{k}, \mathrm{t}}$ and goodwill impairment loss.

We calculate the $\mathrm{B} / \mathrm{M}_{\mathrm{i}, \mathrm{t}}$ ratio as the book value of equity divided by the market value of equity, and expect a positive association between the $\mathrm{B} / \mathrm{M}_{\mathrm{i}, \mathrm{t}}$ ratio and goodwill impairment loss. This is because goodwill represents recognised economic rents, and a higher $\mathrm{B} / \mathrm{M}_{\mathrm{i}, \mathrm{t}}$ ratio indicates the dissipation of both recognised and unrecognised rents. Consistent with this argument, AASB 136.12(d) suggests that a higher book-to-market ratio may indicate asset impairment (AASB, 2014b). Further, Ramanna and Watts (2010) and Li et al. (2010) suggest the B/ $\mathrm{M}_{\mathrm{i}, \mathrm{t}}$ ratio as a proxy for expected goodwill impairment.

United States studies find that United States firms are more likely to report an asset writeoff in year t if they reported an asset write-off in year t-1 (Elliott and Hanna, 1996; Francis et al, 1996). Following this finding, we include lagged goodwill impairment loss IMPR $_{\mathrm{i}, \mathrm{t}-1}$ or $\mathrm{DIMPR}_{\mathrm{i}, \mathrm{t}-}$ 1) as an independent variable to control for prior-year goodwill impairment loss. 


\subsection{Contracting incentives}

We include four contracting incentive variables in our models: (a) leverage $\left(\mathrm{LEV}_{\mathrm{i}, \mathrm{t}}\right)(\mathrm{b})$ size (SIZE $\left.\mathrm{i}_{\mathrm{t},}\right)$, (c) CEO first year $\left(\mathrm{CEOFT}_{\mathrm{i}, \mathrm{t}}\right)$, and (d) CEO last year $\left(\mathrm{CEOLT}_{\mathrm{i}, \mathrm{t}}\right)$.

Prior studies use leverage to proxy for debt covenant restrictions (Fields et al., 2001). The higher the leverage, the more often managers are likely to engage in income-increasing earnings management. Riedl (2004) reports a significantly negative association between leverage and asset write-offs. Thus, we expect a negative relation between leverage and impairment loss. Leverage is measured as the total liabilities divided by total assets at the end of year $t$.

Size is used widely as an independent variable in the earnings management literature (Watts and Zimmerman, 1986). Prior studies on asset write-off also include size as an independent variable ( $\mathrm{Li}$ et al., 2010). The earnings management literature predicts that managers of large firms tend to choose income-decreasing accounting policies in the current year (Watts and Zimmerman, 1986). This suggests a positive association between size and goodwill impairment. Li et al. (2010) find a significantly positive association between size and goodwill impairment in one of three regressions. Size is measured as the natural log of total assets at the end of year $\mathrm{t}$.

Prior research suggests that new CEOs are likely to deflate reported income in their first years as CEOs, as this would create opportunities for them to inflate reported profit in later years (Loh and Tan, 2002; Pourciau, 1993; Riedl, 2004). Since goodwill impairment loss could be used to deflate reported profit, this paper predicts a positive association between $\mathrm{CEOFT}_{\mathrm{i}, \mathrm{t}}$ and impairment loss (Loh and Tan, 2002; Pourciau, 1993; Riedl, 2004). CEOFT $i, t$ takes a value of one if year $t$ is the first year of the CEO of firm i and zero otherwise. On the other hand, the variable, CEOLT $_{i, t}$, takes a value of one if year $t$ is the last year of the CEO of firm $i$ and zero otherwise. A CEO may inflate reported profit in the last year of his/her tenure to enhance the value of the firm's stock options, and the manager's personal value in the managerial labour market. Hence, we predict a negative association between CEOLT $_{\mathrm{i}, \mathrm{t}}$, and goodwill impairment loss. 


\subsection{Reporting flexibility}

One variable for reporting flexibility is the number of operating segments (SEG) (Zhang and Zhang, 2007). AASB 136 requires that goodwill, on acquisition, be allocated to each of the acquirer's CGUs, or groups of CGUs, that is expected to benefit from the synergies of the combination (AASB, 2014b, para 80). If the synergistic effects of goodwill are generated jointly by the CGUs, the allocation of goodwill will be likely to be arbitrary (Ramanna and Watts, 2010). For a given firm, the larger the number of CGUs and the larger the size of those units relative to goodwill, the greater the discretion for management in allocating goodwill to CGUs (Ramanna and Watts, 2010). This flexibility in allocation creates opportunities to manipulate goodwill impairment loss. For example, managers may allocate goodwill to units having higher growth rates, to avoid reporting impairment loss. Alternatively, they can allocate goodwill to units having lower growth rates, to accelerate the reporting of goodwill impairment loss (Ramanna and Watts, 2010). Hence, we do not predict any sign of an association between the number of segments and goodwill impairment loss. Following Ramanna and Watts (2010), we measure SEG as the natural $\log$ of the number of operating segments.

\subsection{Governance index}

We examine the impact of corporate governance in goodwill impairment decisions and, following the regulatory literature, focus on the board of directors and the independent auditor to construct our governance index (GI). We do so, because the literature recognises the board and the auditor as the primary governance agents who have monitoring roles over the entity's financial reporting process (ASX Corporate Governance Council, 2007; Cadbury Report, 1992; National Commission on Fraudulent Financial Reporting, 1987). More specifically, our GI is based on the following six indicators of corporate governance: (a) board independence, (b) audit 
committee independence, (c) Big 4 auditors, (d) financial expertise of the audit committee, (e) frequency of audit committee meetings, and (f) CEO duality. Both the regulatory literature and research inform our choice of these six indicators of corporate governance. For example, the UK Cadbury Report (1992) emphasizes the role of the board of directors (e.g., independent directors and the audit committee) and the auditor, to ensure the quality of accounting information disseminated to shareholders. Similarly, the National Commission on Fraudulent Financial Reporting (1987) places weight on the audit committee and the auditor to ensure reliable corporate financial reporting. On the other hand, the ASX Corporate Governance Council (2007) notes the importance of board and audit committee independence, audit committee financial expertise, separation between the positions of the CEO and the board chair, and frequent meetings of the audit committee in ensuring the integrity of an entity's financial reporting. International Standards on Auditing (ISAs) require the independent auditor to obtain reasonable assurance on whether financial statements are presented fairly in accordance with the applicable reporting framework (IFAC, 2012).

Also, prior research documents that these six aspects of corporate governance constrain management's accounting discretion and are associated with higher financial reporting quality. For example, research finds that Big 4 auditors (Becker et al., 1998; Blokdijk et al., 2006; Dechow et al., 1996; Francis et al., 1999; Francis and Wang, 2008), independent directors on the board (Beasley, 1996; Cheng and Courtenay, 2006; Dechow et al., 1996; Peasnell et al., 2005), independent directors of the audit committee (Klein, 2002), financial expertise of audit committee members (Abbott et al., 2004; DeZoort and Salterio, 2001; Kalbers and Fogarty, 1993; Myers, 2001; Scarbrough et al., 1998; Raghunandan et al., 2001), separation between the CEO and the board chair (Dechow et al., 1996) and frequent meetings of the audit committee (McMullen and Raghunandan, 1996; Xie et al., 2003) are all associated positively with financial reporting quality.

This study develops a composite governance index (GI) by adding one to the index if (a) more than two-thirds of the board members are independent directors, (b) more than two-thirds 
of the audit committee members are independent ${ }^{7}$, (c) the firm is audited by a Big 4 auditor, (d) at least one audit committee member is a professional accountant, (e) the number of audit committee meetings is above the median of the sample, and (f) the CEO is not the board chair. Thus, the GI may take a value between zero and six (both inclusive), zero being the weakest governance and six being the strongest governance. A firm with a GI of zero has none of the governance attributes mentioned above. On the other hand, a firm with a GI of six has all the above governance attributes. Composite governance indices like the one utilised in this study are used widely in the literature (Baber et al., 2012; Baber et al., 2013; Brown et al., 2011). Such a governance index is based on the assumption that the elements of governance included in the index are equally important and are complements rather than substitutes (Brown et al., 2011).

\section{Models}

The following models are estimated for the full sample and two sub-samples: the sub-sample for which GI is at least equal to its median of four (stronger governance subsample) and the subsample comprising the remaining observations (weaker governance sub-sample); separately, to test the hypotheses.

$$
\begin{aligned}
& \text { DIMPR }_{\mathrm{i}, \mathrm{t}}=\alpha+\beta_{1} \Delta \text { SALES }_{\mathrm{i}, \mathrm{t}}+\beta_{2} \Delta \mathrm{CFO}_{\mathrm{i}, \mathrm{t}}+\beta_{3} \text { DPREIN }_{\mathrm{i}, \mathrm{t}}+\beta_{4} \Delta \text { INDRO }_{\mathrm{k}, \mathrm{t}}+\beta_{5} \mathrm{~B} / \mathrm{M}_{\mathrm{i}, \mathrm{t}}+ \\
& \beta_{6} \mathrm{GDPR}_{\mathrm{t}}+\beta_{7} \mathrm{DIMPR}_{\mathrm{i}, \mathrm{t}-1}+\beta_{8} \mathrm{LEV}_{\mathrm{i}, \mathrm{t}}+\beta_{9} \mathrm{SIZE}_{\mathrm{i}, \mathrm{t}}+\beta_{10} \mathrm{CEOFT}_{\mathrm{i}, \mathrm{t}}+ \\
& \beta_{11} \mathrm{CEOLT}_{\mathrm{i}, \mathrm{t}}+\beta_{12} \mathrm{SEG}_{\mathrm{i}, \mathrm{t}}+\mathrm{INDUSTRY}^{+} \mathrm{YEAR}+\varepsilon_{\mathrm{i}, \mathrm{t}} \\
& \text { IMPR }_{\mathrm{i}, \mathrm{t}}=\alpha+\beta_{1} \Delta \text { SALES }_{\mathrm{i}, \mathrm{t}}+\beta_{2} \Delta \mathrm{CFO}_{\mathrm{i}, \mathrm{t}}+\beta_{3} \text { DPREIN }_{\mathrm{i}, \mathrm{t}}+\beta_{4} \Delta \mathrm{INDRO}_{\mathrm{k}, \mathrm{t}}+\beta_{5} \mathrm{~B} / \mathrm{M}_{\mathrm{i}, \mathrm{t}}+ \\
& \beta_{6} \mathrm{GDPR}_{\mathrm{t}}+\beta_{7} \mathrm{IMPR}_{\mathrm{i}, \mathrm{t}-1}+\beta_{8} \mathrm{LEV}_{\mathrm{i}, \mathrm{t}}+\beta_{9} \mathrm{SIZE}_{\mathrm{i}, \mathrm{t}}+\beta_{10} \mathrm{CEOFT}_{\mathrm{i}, \mathrm{t}}+\beta_{11} \mathrm{CEOLT}_{\mathrm{i}, \mathrm{t}} \\
& +\beta_{12} \mathrm{SEG}_{\mathrm{i}, \mathrm{t}}+\text { INDUSTRY }+ \text { YEAR }+\varepsilon_{\mathrm{i}, \mathrm{t}}
\end{aligned}
$$

\footnotetext{
${ }^{7}$ ASX Corporate Governance Council (2007, Recommendation 2.1 and 4.2) recommends a majority of independent directors on the board and the audit committee. We develop our governance index based on stricter independence rules (i.e., two-thirds of the board and the audit committee members being independent) to ensure there is variation in our governance index in our sample. However, we developed an alternative governance index based on the ASX Corporate Governance Council (2007) recommendations of a majority of independent directors on both the board and the audit committee and re-ran the analyses. The results (not tabulated in the paper) are qualitatively similar to those using the two-thirds independent directors rules.
} 
where:

$\operatorname{DIMPR}_{\mathrm{i}, \mathrm{t}} \quad=\quad$ one if firm $\mathrm{i}$ reports goodwill impairment loss in year $\mathrm{t}$ and zero otherwise,

$\operatorname{IMPR}_{\mathrm{i}, \mathrm{t}}=\quad$ goodwill impairment loss of firm $\mathrm{i}$ in year $\mathrm{t}$ divided by total assets at the end of year $t-1$,

$\Delta$ SALES $_{\mathrm{i}, \mathrm{t}}=\quad$ change in sales of firm i in year $\mathrm{t}$ divided by year $\mathrm{t}-1$ sales,

$\Delta \mathrm{CFO}_{\mathrm{i}, \mathrm{t}}=\quad$ change in cash flow from operation of firm $\mathrm{i}$ in year $\mathrm{t}$ divided by total assets at the end of year $t-1$,

DPREIN $_{\mathrm{i}, \mathrm{t}} \quad=\quad$ one if pre-impairment income (calculated as pre-tax profit plus impairment loss) of firm $\mathrm{i}$ in year $\mathrm{t}$ is positive and zero otherwise,

$\Delta \mathrm{INDRO}_{\mathrm{k}, \mathrm{t}} \quad=\quad$ change in median return on assets of industry $\mathrm{k}$ in year $\mathrm{t}$,

$\mathrm{B} / \mathrm{M}_{\mathrm{i}, \mathrm{t}} \quad=\quad$ book to market ratio of firm i in year $\mathrm{t}$,

GDPR $_{\mathrm{t}} \quad=\quad$ gross domestic product growth rate in year $\mathrm{t}$,

DIMPR $_{\mathrm{i}, \mathrm{t}-1}=\quad$ one if firm i reports goodwill impairment loss in year $\mathrm{t}-1$ and zero otherwise,

$\mathrm{IMPR}_{\mathrm{i}, \mathrm{t}-\mathrm{1}}=\quad$ goodwill impairment loss of firm i in year $\mathrm{t}-1$ divided by total assets at the end of year $\mathrm{t}-2$,

$\mathrm{LEV}_{\mathrm{i}, \mathrm{t}}=$ total liabilities divided by total assets of firm $\mathrm{i}$ at the end of year $\mathrm{t}$,

SIZE $_{\mathrm{i}, \mathrm{t}}=$ natural $\log$ of total assets of firm $\mathrm{i}$ at the end of year $\mathrm{t}$,

CEOFT $_{\mathrm{i}, \mathrm{t}}=$ one if year $\mathrm{t}$ is the first year of the CEO and zero otherwise,

CEOLT $_{i, t}=$ one if year $\mathrm{t}$ is the last year of the CEO and zero otherwise,

$\mathrm{SEG}_{\mathrm{i}, \mathrm{t}} \quad=\quad$ natural $\log$ of the number of segments of firm $\mathrm{i}$ in year $\mathrm{t}$,

INDUSTRY $\quad=\quad$ Industry dummies

YEAR $\quad=\quad$ Year dummies

Model (1) is estimated using logit regression, as DIMPR $\mathrm{i}_{\mathrm{i}, \mathrm{t}}$ is a binary variable. On the other hand, model (2) is estimated using Tobit regression, because IMPR $\mathrm{R}_{\mathrm{i}, \mathrm{t}}$ is zero for a significant fraction of the sample. Since the corporate governance of each firm is 'sticky' (stable) over the years and so does not change much each year, the residuals of each firm may be correlated over the years. To 
correct for correlated residuals, we estimate and report model (1) using logit with robust standard errors clustered by firms. ${ }^{8}$

Statistically significant negative signs on five economic factors: $\triangle \mathrm{SALES}_{\mathrm{i}, \mathrm{t}}, \Delta \mathrm{CFO}_{\mathrm{i}, \mathrm{t}}$, $\operatorname{DPREIN}_{\mathrm{i}, \mathrm{t}}, \mathrm{INDRO}_{\mathrm{k}, \mathrm{t}}$ and $\mathrm{GDPR}_{\mathrm{t}}$ and a positive sign on $\mathrm{B} / \mathrm{M}_{\mathrm{i}, \mathrm{t}}$ in models (1) and (2) would suggest associations between economic factors and goodwill impairment loss. Positive signs on DIMPR $\mathrm{R}_{\mathrm{i}, \mathrm{t}}$ 1 and IMPR $\mathrm{R}_{\mathrm{i}, \mathrm{t}-1}$ would suggest a positive association between current year goodwill impairment loss, and immediately prior-year impairment loss. On the other hand, the statistically significant negative signs on $\mathrm{LEV}_{\mathrm{i}, \mathrm{t}}$ and CEOLT $\mathrm{T}_{\mathrm{i}, \mathrm{t}}$ and positive signs on $\mathrm{SIZE}_{\mathrm{i}, \mathrm{t}}$ and CEOFT $\mathrm{i}, \mathrm{in}$ models (1) and (2) would indicate associations between contracting incentives and goodwill impairment loss.

$\mathrm{H} 1$ suggests that the associations between economic factors (i.e., $\triangle \mathrm{SALES}_{\mathrm{i}, \mathrm{t}}, \Delta \mathrm{CFO}_{\mathrm{i}, \mathrm{t}}$ $\operatorname{DPREIN}_{\mathrm{i}, \mathrm{t}}, \mathrm{INDRO}_{\mathrm{k}, \mathrm{t}} \mathrm{B} / \mathrm{M}_{\mathrm{i}, \mathrm{t}}$ and $\mathrm{GDPR}_{\mathrm{t}}$ ) and impairment loss (i.e., DIMPR $\mathrm{R}_{\mathrm{i}, \mathrm{t}}$ and $\operatorname{IMPR}_{\mathrm{i}, \mathrm{t}}$ ) are stronger for the stronger governance sub-sample than for the weaker governance sub-sample. On the other hand, H2 suggests that the associations between contracting incentive variables

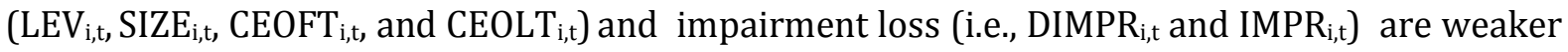
for the stronger governance sub-sample than for the weaker governance sub-sample.

\section{Data and sample}

The population for this study is all non-financial firms ${ }^{9}$ listed in the Australian Securities Exchange that have goodwill. A firm is initially included in the sample for year $t$ if the firm reported goodwill in the year $\mathrm{t}_{-1}$ or $\mathrm{t}$ balance sheet. Financial statement data, except goodwill, goodwill impairment loss and number of segments, are collected from Datastream, while data on goodwill, goodwill impairment loss, number of segments and companies' corporate governance

\footnotetext{
${ }^{8}$ Stata allows the estimation of logit regression using standard errors clustered by firms. However, Tobit regression with standard errors clustered by firms cannot be estimated using Stata.

${ }^{9}$ Consistent with prior studies (Bradbury et al., 2003; Riedl, 2004), financial firms are excluded from the sample because these firms are subject to financial and reporting regulations different from other industries and have unique financial structures.
} 
are collected from their annual reports. The first year in the sample is 2007 because 2006 is the first year of IFRS adoption for many Australian companies. Hence, 2006 financial statements for these companies are affected by the transition to IFRS. The last year in the sample is 2012, because data were collected for this study during 2013, and 2012 was the last year for which data were available.

Table 1 (Panel A) shows that the initial sample comprises 1,960 firm-years with goodwill. 177 firm-years are excluded from the initial sample, because 34 have negative book values of stockholders' equity and 143 have no data on model variables. This yields the final sample of 1,783 firm-years with 371 firm-years having goodwill impairment loss. Thus, around $21 \%$ of the firm-years have goodwill impairment loss. Chalmers et al.'s (2011) sample comprises 1,432 firmyear observations under A-IFRS. As Table 1 (Panel B) shows, the sample includes a similar number of observations from each of the sample years 2007-2012, except 2012, which contributes 202 firm-years to the sample. The reason for the smaller number of observations in 2012 is that we collected data in 2013 and not all Australian listed companies' data for 2012 were available at that time. Table 1 (panel C) shows that the sample is from 34 industries.

\section{Table 1 about here}

\section{Findings}

\subsection{Descriptive statistics}

Table 2 reports descriptive statistics of model variables for two sub-samples. The first sub-sample comprises firm-year observations with reported goodwill impairment loss (impairment sub-sample), and the second sub-sample comprises firm-year observations with no reported goodwill impairment loss (no impairment sub-sample). As Table 2 shows, compared with the no impairment sub-sample, the impairment sub-sample has lower sales growth 
$\left(\triangle \mathrm{SALES}_{\mathrm{i}, \mathrm{t}}\right)$, slower growth in cash flow from operating activities $\left(\Delta \mathrm{CFO}_{\mathrm{i}, \mathrm{t}}\right)$, less frequent positive pre-impairment income (DPREIN $\left.\mathrm{i}_{\mathrm{i}, \mathrm{t}}\right)$, higher book-to-market ratio $\left(\mathrm{B} / \mathrm{M}_{\mathrm{i}, \mathrm{t}}\right)$, higher leverage $\left(\mathrm{LEV}_{\mathrm{i}, \mathrm{t}}\right)$, a higher number of operating segments $\left(\mathrm{SEG}_{\mathrm{i}, \mathrm{t}}\right)$, and better governance $\left(\mathrm{GI}_{\mathrm{i}, \mathrm{t}}\right)$. The table also reveals that goodwill impairment loss in year t-1 is likely to be followed by goodwill impairment loss in year t. Further, goodwill impairment is mostly reported when the industry is performing poorly, the GDP growth rate $\left(\mathrm{GDPR}_{\mathrm{t}}\right)$ is lower, and in the first and last years of the term of the CEO. Thus, the descriptive statistics suggest that goodwill impairment loss is associated with both economic factors and contracting incentives.

Table 2 about here

Table 3 reports the correlations between independent variables. For the convenience of presentation, we report only the correlation coefficients between pairs of economic factors and contracting incentive variables. The correlation coefficients between pairs of economic factors and contracting incentives are low in magnitude. For example, the highest correlation coefficient is 0.430 between $\mathrm{SIZE}_{\mathrm{i}, \mathrm{t}}$ and $\mathrm{SEG}_{\mathrm{i}, \mathrm{t}}$. Therefore, the economic factors and contracting incentive variables represent different aspects of the economic and reporting environment that affect goodwill impairment. Further, the low magnitudes of correlations between pairs of economic factors and contracting incentives suggest that multicollinearity does not pose any serious problem for models (1) and (2). The Variance Inflation Factors (VIF) of the independent variables, which are all less than 3 , confirm this.

Table 3 about here

\subsection{Regression analyses}


Table 4 reports the results of running model (1) and (2) for the full sample, the stronger governance (i.e., DGI = 1) sub-sample, and the weaker governance (i.e., DGI = 0) sub-sample. In model (1), as expected, the coefficient of pre-impairment income (i.e., DPREIN $\mathrm{i}_{\mathrm{i}, \mathrm{t}}$ ) is negative and significant at less than $1 \%$, and those of the book-to-market ratio (i.e., $\mathrm{B} / \mathrm{M}_{\mathrm{i}, \mathrm{t}}$ ) and lagged impairment dummy (i.e., DIMPR $\mathrm{R}_{\mathrm{i},-1}$ ) are positive and significant at conventional levels for the full sample. However, these results do not hold equally well for the stronger and weaker governance sub-samples. For example, the coefficients of DPREIN $\mathrm{i}_{\mathrm{i}, \mathrm{t}}$ and DIMPR $\mathrm{R}_{\mathrm{i},-1}$ are significant and have the predicted signs for both sub-samples. But sales growth $\left(\triangle \mathrm{SALES}_{\mathrm{i}, \mathrm{t}}\right)$, change in cash flow $\left(\Delta \mathrm{CFO} \mathrm{i}_{\mathrm{i}, \mathrm{t}}\right)$, book-to-market ratio $\left(\mathrm{B} / \mathrm{M}_{\mathrm{i}, \mathrm{t}}\right)$ and GDP growth rate $\left(\mathrm{GDPR}_{\mathrm{t}}\right)$ have the predicted signs and are statistically significant for the stronger governance sub-sample only (i.e., DGI = 1), and not for the weaker goverance sub-sample (i.e., DGI = 0). These results support H1.

However, contrary to $\mathrm{H} 2$, the coefficient of $\mathrm{CEOFT}_{\mathrm{i}, \mathrm{t}}$ is positive and significant for the full sample and the two governance sub-samples, suggesting that the likelihood of reporting goodwill impairment loss is higher in the first year of the CEO, irrespective of the strength of the firm's governance. These results do not support H2. Further, contrary to the contracting incentive explanation, the coefficient on leverage $\left(\mathrm{LEV}_{\mathrm{i}, \mathrm{t}}\right)$ is positive and significant for the full sample as well as the two governance sub-samples, but that on size (SIZE $\left.\mathrm{E}_{\mathrm{i}, \mathrm{t}}\right)$ is positive and significant for the full sample only, and that on segments $\left(\mathrm{SEG}_{\mathrm{i}, \mathrm{t}}\right)$ is positive and significant for the full sample and the stronger governance sub-sample.

\section{Table 4 about here}

The results are similar for model (2). While the coefficients on four economic factors: change in cash flow $\left(\Delta \mathrm{CFO}_{\mathrm{i}, \mathrm{t}}\right)$, pre-impairment income (DPREIN $\left.\mathrm{N}_{\mathrm{i}, \mathrm{t}}\right)$, book-to-market ratio $\left(\mathrm{B} / \mathrm{M}_{\mathrm{i}, \mathrm{t}}\right)$ and GDP growth rate $\left(G_{D P R}\right)$; are significant and have the predicted signs for the stronger governance sub-sample (i.e., DGI = 1), only two: pre-impairment income $\left(\operatorname{DPREIN}_{\mathrm{i}, \mathrm{t}}\right)$ and industry return $\left(\triangle \mathrm{INDRO} \mathrm{k}_{\mathrm{t}}\right)$; are significant with predicted signs for the weaker governance sub-sample 
(i.e., DGI $=0$ ). These results support H1. Further, similar to model (1) but contrary to H2, the coefficient on $\mathrm{CEOFT}_{\mathrm{i}, \mathrm{t}}$ is positive and significant for the full sample and the two governance subsamples.

Taken together, these results support H1. The results further suggest that, regardless of the strength of governance, goodwill impairment loss is more likely to be recorded, and the magnitude of impairment loss is likely to be higher, in the first year of CEO tenure than in other years. This does not support $\mathrm{H} 2$ but is consistent with the observation that CEOs tend to record large impairment losses in the first year of their tenure. ${ }^{10}$

\subsection{Alternative variables and models}

To test the robustness of our results to alternative firm performance variables, we also run models (1) and (2) using two firm performance variables: Tobin's q, and return on assets (ROA); in place of the four firm performance variables: sales growth $\left(\triangle \mathrm{SALES} \mathrm{S}_{\mathrm{i}, \mathrm{t}}\right)$, change in cash flow $\left(\Delta \mathrm{CFO}_{\mathrm{i}, \mathrm{t}}\right)$, pre-impairment income $\left(\mathrm{DPREIN}_{\mathrm{i}, \mathrm{t}}\right)$, and book-to-market ratio $\left(\mathrm{B} / \mathrm{M}_{\mathrm{i}, \mathrm{t}}\right)$. We measure Tobin's q as the value of the firm divided by the book value of total assets, and use it as an independent variable because it provides a measure of the firm's intangible assets (Perfect and Wiles, 1994). Further, the goodwill literature has used Tobin's q as a proxy for the investment opportunity set, which is documented as being associated with goodwill amortisation/impairment loss (Bradbury et al., 2003; Chalmers et al., 2011). The return on assets (ROA) is measured as net income divided by total assets and is used as a measure of performance in the goodwill impairment literature (Chalmers et al., 2011). Both Tobin's q and ROA are associated negatively with the likelihood of recording goodwill impairment loss, irrespective of

${ }^{10}$ For example, the IASB Chairman Hans Hoogervorst notes in an interview with the KPMG that newly appointed CEOs have 'a strong incentive to recognise hefty impairments on their predecessor's acquisitions' so that they can start with a clean slate and report 'a steady flow of earnings' in the future (KPMG, 2014, p. 5). 
the strength of governance. The significance level of ROA is the same $(p=0.00)$ for both governance sub-samples. But the significance level of Tobin's q is lower for the stronger governance sub-sample $(p=0.02)$ than for the weaker governance sub-sample $(p=0.06)$. Further, while ROA is associated negatively at less than $1 \%$ with the magnitude of goodwill impairment loss, for both the stronger and weaker goverance sub-samples, Tobin's q is significant, at less than $1 \%$, for the stronger governance sub-sample only. For the weaker governance sub-sample, Tobin's q is not significant at conventional levels. These results provide further support for H1.

To test the sensitivity of our results to models, we also estimate two models: one for DIMPR $\mathrm{i}_{\mathrm{i}, \mathrm{t}}$ as the dependent variable and the other for IMPR $\mathrm{i}$, ; that include independent variables for each economic factor and contracting incentive, a main-effect continuous variable for the governance index (GI), and interaction variables between the GI and each economic factor and contracting incentive. ${ }^{11}$ The results (not in the table) show that governance strengthens the association between impairment loss (i.e., DIMPR $\mathrm{i}_{\mathrm{i}, \mathrm{t}}$ and $I M P \mathrm{R}_{\mathrm{i}, \mathrm{t}}$ ) and two economic factors: change in cash flow $\left(\Delta \mathrm{CFO}_{\mathrm{i}, \mathrm{t}}\right)$ and the book-to-market ratio $\left(\mathrm{B} / \mathrm{M}_{\mathrm{i}, \mathrm{t}}\right)$. These results are consistent with those obtained using partitioned samples, in Table 4, and support H1. However, governance does not have any impact on the association between contracting incentives and impairment loss.

To check the sensitivity of our results to our governance proxy, we also factor-analysed six aspects of corporate governance: (a) the percentage of independent auditors on the board, (b) the percentage of independent directors on the audit committee, (c) use of a Big 4 auditor, (d) the presence of at least one accounting professional on the audit committee, (e) the frequency of audit committee meetings, and (f) CEO duality. After varimax rotation, two factors with an eigenvalue greater than 1 emerged. These two factors explain approximately $52 \%$ of the variation between the six components of governance. The first factor loads heavily on use of a Big 4 auditor, board independence and audit committee independence, and hence we call this factor "independence". The second factor loads heavily on audit committee meeting frequency and we call this factor

11 We do not use the interacted models as our primary models, as these models suffer from multicollinearity. More specifically, the interaction variables have high VIF. 
"meeting". The factor scores of "independence" and "meeting" are correlated positively with our governance index (GI) ( $r=0.845$ and $r=0.279$, respectively). We interact these factor scores with economic factors and contracting incentive variables, and run the interacted models. The results (not in the table) show that the "independence" factor strengthens the associations between goodwill impairment loss (i.e., DIMPR $\mathrm{R}_{\mathrm{i}, \mathrm{t}}$ and $\mathrm{IMPR}_{\mathrm{i}, \mathrm{t}}$ ) and three economic factors: sales growth, the change in cash flow and the book-to-market ratio. Again, these results support H1. The results (not in the table) also show that the likelihood of reporting goodwill impairment loss is higher in the first year of the CEO's tenure irrespective of the independence of the firm's governance. These results do not support H2. Finally, the "meeting" factor strengthens the associations between impairment loss and two economic factors: sales growth and the book-to-market ratio. This result also supports H1.

\subsection{Industry-wise analysis}

To test the sensitivity of our results to industry, we divide our sample into three groups: industries with a median GI score of above 4 (group1), industries whose median GI score is 4 (group2), and industries with a median GI score of below 4 (group3) ${ }^{12}$, and run models (1) and (2) for each of these three groups separately, after excluding the industry dummies. We find that the likelihood of recording goodwill impairment loss is associated with: pre-impairment income, book-to-market ratio, lagged impairment loss and GDP growth rate for group1 firms; preimpairment income, book-to-market ratio and lagged impairment loss for group2 firms; and pre-

12 Group1 firms comprise firms from chemicals, food \& drug retailers, forestry \& paper, gas water \& multiutilities, general industry, industrial metals \& mining, oil equipment \& services, pharmaceuticals $\&$ biotechnology, real estate investment trusts, and real estate investments \& services. Group2 firms comprise beverages, construction \& materials, electricity, food products, general retailers, healthcare equipment \& services, household goods \& home construction, industrial engineering, media, mining, software \& computer services, support services, technology equipment \& services, and travel \& leisure. Finally, group3 firms comprise aerospace \& defence, alternative energy, automobiles \& parts, electrical $\&$ electronic equipment, fixed-line telecommunications, industrial goods, industrial transportation, mobile telecommunications, oil \& gas products, and personal goods. 
impairment income and lagged impairment loss for group3 firms. Therefore, the higher the governance score for industries, the higher the number of economic factors with which the likelihood of reporting goodwill impairment loss is associated. This result supports the hypothesis (i.e., H1) that stronger governance strengthens the associations between economic factors and goodwill-impairment loss likelihood.

The magnitude of goodwill impairment loss is associated with pre-impairment loss and book-to-market ratio for group1 and group2 firms, and with pre-impairment income and change in industry median return for group3 firms. Further, consistent with the results reported above, the variable $\mathrm{CEOFT}_{\mathrm{i}, \mathrm{t}}$ is positive and significant for all three groups, suggesting that firms are more likely to record goodwill impairment loss, and that this loss is likely to be larger, in the first year of a CEO's tenure than in other years, regardless of the governance strength of the industires.

\subsection{Propensity-matched sample}

We use the propensity score matching (PSM) methodology to control for potential selfselection bias. We use PSM instead of the Heckman correction, because our no-impairment-loss observations far outnumber our impairment-loss observations. Also, identifying an instrument for the Heckman correction procedure is difficult.

PSM involves matching treatment firms with non-treatment/control firms having similar characteristics, according to the function of covariates (Rosenbaum \& Rubin, 1983, 1985). Following the steps for propensity score matching, we divide our sample into two groups: impairment-loss and no-impairment-loss.

We calculate the propensity score as the predicted probability from the probit model that regresses the likelihood of goodwill impairment loss on five economic factors ${ }^{13}$. Based on that

${ }^{13}$ The five economic factors are sales growth, change in cash flow, pre-impairment income, book-tomarket ratio and GDP grouth rate. We do not include change in industry return as an independent variable in the matching regression, because the balancing property was not satisfied for this factor. 
propensity score, we match each impairment loss firm-year observation with a no-impairment loss firm-year observation by applying two matching methods: the nearest neighbour method and the radius-matching method. For the radius-matching method, we apply a radius of 0.10 . The balancing property was satisfied for the five economic factors. After constructing the matched sample, we test whether there is any significant difference in the governance score between the impairment-loss and the no-impairment-loss sub-samples. We find that the impairment-loss subsample has a higher governance score than the no-impairment-loss sub-sample under both matching methods, and the difference in governance scores is significant, at a less than $5 \%$ level of significance. These results suggest that, even after controlling for the propensity to record goodwill impairment loss, an impairment-loss sub-sample is likely to have stronger governance than a no-impairment-loss sub-sample.

\subsection{Impact of each governance attribute}

So far, we have examined the impact of governance on goodwill impairment using a composite index of governance. Using an index comprised of six governance attributes, we find that governance improves the associations between goodwill impairment loss and economic factors. We also find that the likelihood and the magnitude of goodwill impairment loss are likely to be higher in the first year of CEO tenure than in other years. Then, using the two governance factors "independence" and "meeting" derived from factor analysis of six governance attributes, we find similar results. However, it is not clear whether each of the six governance attributes has the same impact as the composite index. To investigate this, we re-run models (1) and (2) for subsamples based on the following six partitioning governance variables:

BIND $=\begin{aligned} & \text { one if two-thirds of the board members are independent, zero } \\ & \text { otherwise }\end{aligned}$
ACIND $=\begin{aligned} & \text { one if two-thirds of the members of the audit committee are } \\ & \text { independent, zero otherwise }\end{aligned}$
BIG4 $=$ one if the firm-year observation has a Big 4 auditor, zero otherwise




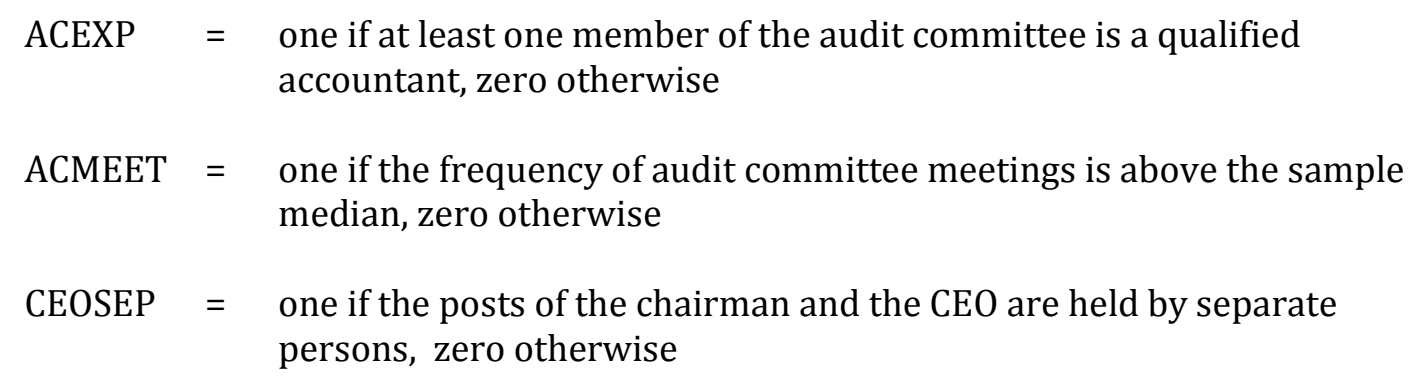

\section{Table 5 about here}

Table 5 reports the results of this analysis. Panel A, which reports the results for model (1) for twelve sub-samples, shows that all six governance attributes: board independence, audit committee independence, Big4 auditor, audit committee expertise, audit committee meeting frequency and CEO separation; strengthen the associations between economic factors and the likelihood of reporting goodwill impairment loss. For example, the likelihood of goodwill impairment loss is associated negatively with: (a) the change in cash flow $\left(\Delta \mathrm{CFO}_{\mathrm{i}, \mathrm{t}}\right)$, the preimpairment income $\left(\operatorname{DPREIN}_{\mathrm{i}, \mathrm{t}}\right)$ and the book-to-market ratio $\left(\mathrm{B} / \mathrm{M}_{\mathrm{i}, \mathrm{t}}\right)$ when $\mathrm{BIND}=1,(\mathrm{~b})$ the change in cash flow $\left(\Delta C \mathrm{CO}_{\mathrm{i}, \mathrm{t}}\right)$, the pre-impairment income $\left(\mathrm{DPREIN}_{\mathrm{i}, \mathrm{t}}\right)$ and the book-to-market ratio $\left(B / M_{i, t}\right)$ when $A C I N D=1$, (c) the pre-impairment income (DPREIN $\left.N_{i, t}\right)$, the change in industry return $\left(\triangle \mathrm{INDRO}_{\mathrm{k}, \mathrm{t}}\right)$, the book-to-market ratio $\left(\mathrm{B} / \mathrm{M}_{\mathrm{i}, \mathrm{t}}\right)$ and the GDP growth rate $\left(\mathrm{GDPR}_{\mathrm{t}}\right)$ when BIG4=1, (d) the change in cash flow $\left(\Delta \mathrm{CFO}_{\mathrm{i}, \mathrm{t}}\right)$, the pre-impairment income (DPREIN $\left.\mathrm{i}_{\mathrm{i}, \mathrm{t}}\right)$ and the book-to-market ratio $\left(\mathrm{B} / \mathrm{M}_{\mathrm{i}, \mathrm{t}}\right)$ when $\mathrm{ACEXP}=1$, (e) the pre-impairment income $\left(\operatorname{DPREIN}_{\mathrm{i}, \mathrm{t}}\right)$, the book-to-market ratio $\left(\mathrm{B} / \mathrm{M}_{\mathrm{i}, \mathrm{t}}\right)$ and the GDP growth rate $\left(\mathrm{GDPR}_{\mathrm{t}}\right)$ when ACMEET $=1$, and $(\mathrm{f})$ the pre-impairment income (DPREIN $\mathrm{i}_{\mathrm{i}, \mathrm{t}}$, the book-to-market ratio $\left(\mathrm{B} / \mathrm{M}_{\mathrm{i}, \mathrm{t}}\right)$ and the GDP growth rate $\left(\mathrm{GDPR}_{\mathrm{t}}\right)$ when CEOSEP=1.

In contrast, the only economic factor with which the goodwill impairment dummy is consistently associated, with the predicted sign, for all the sub-samples having partitioning governance variables of zero, is the pre-impairment income (DPREIN $\mathrm{i}_{\mathrm{i}, \mathrm{t}}$ ). Besides pre-impairment 
income, GDP growth rate (GDPR $)$ and sales growth are associated with the impairment dummy when BIND $=0$ and CEOSEP $=0$, respectively .

Panel A results have three more salient features. First, as reflected in the significantly positive coefficient of DIMPR $\mathrm{i}_{\mathrm{i}, \mathrm{t}-1}$, goodwill impairment loss in year t-1 is likely to be followed by goodwill impairment loss in year $t$, in eleven of the twelve sub-samples. Second, CEOFT $\mathrm{i}_{\mathrm{t}, \mathrm{has}}$ significantly positive coefficients in five sub-samples where the partitioning variables (BIND, ACIND, BIG4, ACEXP and CEOSEP) take the value of one, and three sub-samples where the partitioning variables (BIND, ACMEET and CEOSEP) take the value of zero, suggesting that goodwill impairment loss is more likely to be reported in the first year of the CEO's tenure irrespective of the strength of governance. This evidence does not support H2. Third, the coefficient of $\mathrm{SEG}_{\mathrm{i}, \mathrm{t}}$ is significantly positive in nine of the twelve sub-samples, suggesting that goodwill impairment loss is likely to be reported by firms having a higher number of segments.

Similar results are obtained for the magnitude of goodwill impairment loss (IMPR $\mathrm{R}_{\mathrm{i}, \mathrm{t}}$ ), shown in Panel B. Three governance attributes: Big4 auditor, audit committee expertise, and CEO separation; strengthen the associations between economic factors and the magnitude of goodwill impairment loss. For example, Panel B reveals that $\mathrm{IMPR}_{\mathrm{i}, \mathrm{t}}$ is associated, significantly and negatively, with (a) pre-impairment income (DPREIN $\mathrm{i}_{\mathrm{i}, \mathrm{t}}$ ), the change in industry median return $\left(\Delta \mathrm{INDRO}_{\mathrm{k}, \mathrm{t}}\right)$, the book-to-market ratio $\left(\mathrm{B} / \mathrm{M}_{\mathrm{i}, \mathrm{t}}\right)$ and the GDP growth rate $\left(\mathrm{GDPR}_{\mathrm{t}}\right)$ when $\mathrm{BIG} 4=1$, (b) the change in cash flow $\left(\Delta \mathrm{CFO}_{\mathrm{i}, \mathrm{t}}\right)$, the pre-impairment income (DPREIN $\left.\mathrm{i}_{\mathrm{t},}\right)$, the book-to-market ratio $\left(B / M_{i, t}\right)$ and the GDP growth rate $\left(G \mathrm{GPR}_{t}\right)$ when $\operatorname{ACEXP}=1$, and $(\mathrm{c})$ the sales growth $\left(\triangle \mathrm{SALES}_{\mathrm{i}, \mathrm{t}}\right)$, the pre-impairment income $\left(\operatorname{DPREIN}_{\mathrm{i}, \mathrm{t}}\right)$, the change in industry median return $\left(\triangle \mathrm{INDRO}_{\mathrm{k}, \mathrm{t}}\right)$ and the GDP growth rate $\left(\mathrm{GDPR}_{\mathrm{t}}\right)$ when CEOSEP $=1$. However, only pre-impairment income (DPREIN $\mathrm{i}_{\mathrm{i}, \mathrm{t}}$ ) is associated with impairment loss when these three governance attributes take the value of zero. Besides this, the change in industry return $\left(\triangle \mathrm{INDRO}_{\mathrm{k}, \mathrm{t}}\right)$ is associated with impairment loss when ACEXP $=0$. The evidence is mixed with regard to the remaining three governance attributes (i.e., board independence, audit committee independence and audit 
committee meeting). Overall, the results strongly support the hypothesis that stronger corporate governance strengthens the association between economic factors and goodwill impairment loss.

With regard to the CEO first year variable $\left(\mathrm{CEOFT}_{\mathrm{i}, \mathrm{t}}\right)$, results similar to those in Panel A are obtained in Panel B also, in that the variable is associated positively with the magnitude of impairment loss in eight of the twelve sub-samples, thus strongly suggesting that higher goodwill impairment loss is recorded in the first year of the CEO's tenure. As in Panel A, the segment variable $\left(\mathrm{SEG}_{\mathrm{i}, \mathrm{t}}\right)$ is associated positively with impairment loss in the majority of sub-samples.

\subsection{Goodwill impairment loss and big bath}

In this sub-section, we test the possibility that goodwill impairment loss is used by firms as a big-bath tool. We find that goodwill impairment loss is significantly negatively associated with pre-impairment income across all sub-samples, suggesting that goodwill impairment loss is more likely to be reported when pre-impairment income is negative. This is consistent with goodwill impairment loss reflecting poor performance of the entity. However, this result is also consistent with goodwill impairment loss used as a big-bath tool, in that impairment loss is recorded to shift future losses to an already poor year. We try to amplify our evidence for the big bath argument by doing three further tests.

\section{Table 6 about here}

In our first test, we consider all those firm-year observations $(n=465)$ that have negative pre-impairment income. We divide these observations into "impairment" and "no impairment" sub-samples. We then compare the return on assets (ROA) ${ }^{14}$ of these two sub-samples to see the impact of goodwill impairment loss. Panel A of Table 6 shows that the mean (median) ROA of the

\footnotetext{
${ }^{14}$ Return on assets (ROA) is calculated as net income divided by total assets.
} 
impairment sub-sample is $-0.508(-0.226)$, which is much less than the corresponding amount (i.e., -0.193 and -0.099 , respectively, for mean and median ROA) of the no impairment sub-sample (significant at less than 1 percent). The large magnitude of net loss of the impairment loss subsample suggests that firms in this sub-sample most probably use goodwill impairment loss as a big-bath tool.

Our second test provides further support for the above explanation. Here we consider the goodwill impairment loss sample $(\mathrm{n}=371)$. We then divide this sample into two sub-samples: "positive pre-impairment income" and "negative pre-impairment income"; and compare the ROA of these two sub-samples. Panel B shows that the mean and median ROA of the negative preimpairment income sub-sample $(-0.508$ and -0.226 , respectively) is much less than the corresponding amounts ( 0.013 and 0.026 , respectively) of the positive pre-impairment income sub-sample. This result provides further support for the hypothesis that goodwill impairment loss is used as a big-bath tool when pre-impairment income is negative.

Our third test of big bath involves using an alternative variable, $\triangle \mathrm{PREIN} \mathrm{N}_{\mathrm{i}, \mathrm{t}}$ in place of DPREIN $_{\mathrm{i}, \mathrm{t}}$ in models (1) and (2). $\triangle$ PREIN $_{\mathrm{i}, \mathrm{t}}$, is equal to the change in pre-impairment income (scaled by total assets) if the change in pre-impairment income is negative, and zero otherwise. While DPREIN $\mathrm{i}_{\mathrm{i}, \mathrm{t}}$ is consistent with an earnings target of avoiding loss, $\triangle$ PREIN $_{\mathrm{i}, \mathrm{t}}$ is consistent with an earnings target of avoiding an earnings decline. Both earnings targets are widely used in the earnings management literature (Walker, 2013). A negative and significant sign on $\triangle$ PREIN $N_{i, t}$ would be consistent with the big-bath hypothesis, as it would indicate that managers tend to report goodwill impairment loss when income declines. Results (not in the table) show that $\triangle$ PREIN $\mathrm{i}_{\mathrm{i}, \mathrm{t}}$ is negative and significant at a less than $5 \%$ level of significance for both the stronger governance and weaker governance sub-samples. Similar results (not in the table) are observed when we use a binary variable for the decline in pre-impairment income.

We also document that, regardless of the strength of governance, the likelihood and the magnitude of goodwill impairment loss are likely to be higher in the first year of a CEO's tenure. Since the prior literature suggests that CEOs take a big bath in their first year to put the blame on 
the outgoing CEO and start with a clean slate (Sunder, 1997), we now test the possibility that goodwill impairment loss is used as a big-bath tool by CEOs in their first year. We find that firms, on average, report a larger goodwill impairment loss and larger net loss (deflated by total assets) in the first year of their CEO than in other years. The mean goodwill impairment loss and net loss in the first year of the CEO (in other years of the CEO tenure) are $0.044(0.023)$ and -0.138 (0.001), respectively (results not in the table). The t-statistics for differences in means are significant at conventional levels. Results remain similar with non-parametric tests of differences in medians. Thus, poor financial performance in the first year of the CEO is followed by performance improvement in the later years of the CEO's tenure, a typical characteristic of the big-bath phenomenon (Sunder, 1997). Even for the impairment loss sub-sample (i.e., n=371), much higher goodwill impairment loss (a median of 0.055 for CEOs' first year vs. 0.019 for other years) and net loss (a median of -0.103 for CEOs' first year vs. -0.045 for other years) are reported in the first year of a CEO than in other years. The differences in medians are statistically significant. Overall, these results provide evidence that goodwill impairment loss is likely to be used as a big-bath tool, and governance does not have much control over it.

\section{Conclusions}

This paper investigates the role of corporate governance in controlling the accounting discretion involved in goodwill impairment under IFRS in Australia. More specifically, it examines whether corporate governance moderates the associations between goodwill-impairment loss

under AASB 136, and economic indicators of goodwill impairment loss and contracting incentives. The sample comprises 1783 firm-year observations from Australia and covers the period 2007-12.

While consistent with Chalmers et al. (2011), in that goodwill impairment loss is observed to be associated significantly with economic factors, the associations vary depending on the strength of corporate governance. More specifically, the likelihood of goodwill impairment loss is 
associated negatively with pre-impairment income, regardless of the strength of corporate governance. But the likelihood of impairment loss is associated with sales growth, change in cash flow, book-to-market ratio and GDP growth rate only in the stronger governance sub-sample. The coefficients are significant and have the predicted signs. Similar results are obtained with respect to the magnitude of goodwill impairment loss. More specifically, the magnitude of goodwill impairment loss is associated with a change in cash flow, the book-to-market ratio and GDP growth rate only in the stronger governance sub-sample. The results are robust to alternative measures of performance variables and governance, models, and the propensity to impair goodwill.

We also find that the likelihood and the magnitude of goodwill impairment loss are higher in the first year of a CEO's tenure, than they are in later years. Further investigation provides preliminary evidence that firms tend to use goodwill impairment loss as a big-bath tool in the first year of CEO tenure, and when pre-impairment income is negative. Taken together, these results suggest that stronger governance improves the associations between economic factors and goodwill impairment loss, but cannot completely eliminate the opportunistic use of accounting discretion in goodwill impairment.

While prior studies (Beatty and Weber, 2006; Chalmers et al., 2011; Godfrey and Koh, 2009) report that goodwill impairment loss is associated with proxies for economic realities, we document that the associations between goodwill impairment loss and economic indicators of goodwill impairment are more likely to be observed for firms with stronger corporate governance. Furthermore, the corporate governance and financial reporting literature shows that corporate governance improves financial reporting quality (Brown et al., 2011). We document that while stronger corporate governance improves reporting for goodwill impairment loss, it does not eliminate the opportunistic use of accounting discretion involved in goodwill impairment decisions. Therefore, our findings highlight the need for boards (including the audit committee) and for auditors to pay more attention to the opportunistic use of accounting discretion in assessing goodwill impairment. 
The findings of this study are relevant to the regulators of countries that have goodwill impairment regimes and want to improve the implementation of IFRS. One major concern with the adoption of IFRS is the potential for opportunism in the use of accounting discretion. Therefore, the results of this paper are also potentially relevant to those countries planning to adopt IFRS in the future. The results of this study suggest that it is important for companies to have strong corporate governance arrangements to ensure rigorous implementation of IFRS in general, and goodwill accounting in particular. 


\section{References}

Abbott, L., Parker, S., Peters, G., 2004. Audit committee characteristics and restatements. Auditing - J. Pract. Th. 23(1), 69-87.

Ahmed, A. S., Duellman, S., 2007. Accounting conservatism and board of director characteristics: an empirical analysis. J. Account. Econ. 43, 411-437.

Australian Accounting Standards Board (AASB), 1996. AASB 1013 Accounting for goodwill. Available at http://www.aasb.gov.au/admin/file/content102/c3/AASB1013 6-96.pdf (accessed 13 December 2014)

Australian Accounting Standards Board (AASB), 2014a. AASB 116 Property, Plant and Equipment. Available at http://www.aasb.gov.au/admin/file/content105/c9/AASB116 0704 COMPjun14 07-14.pdf (accessed 13 December 2014)

Australian Accounting Standards Board (AASB), 2014b. AASB 136 Impairment of Assets. Available at http://www.aasb.gov.au/admin/file/content105/c9/AASB136 0704 FP COMPdec12 07-13.pdf (accessed 2 September 2014)

Australian Accounting Standards Board (AASB), 2014c. AASB 138 Intangible Assets. Available at http://www.aasb.gov.au/admin/file/content105/c9/AASB138 07-04 COMPjun14 0714.pdf (accessed 13 December 2014)

Australian Securities Exchange (ASX) Corporate Governance Council, 2007. Corporate Governance Principles and Recommendations with 2010 Amendments. Available at http://www.asx.com.au/documents/asxcompliance/cg principles recommendations with 2010 amendments.pdf (accessed 2 September 2012)

Baber, W.R., Liang, L., Zhu, Z., 2012. Associations between internal and external corporate governance characteristics: implications for investigating financial accounting restatements. Account. Horiz. 26 (2), 219-237.

Baber, W.R., Gore, A.K., Rich, K.T., Zhang, J.X., 2013. Accounting restatements, governance and municipal debt financing. J. Account. Econ. 56, 212-227.

Beasley, M.S., 1996. An empirical analysis of the relation between the board of director composition and financial statement fraud. Account. Rev. 71(4), 443-465.

Beatty, A., Weber, J., 2006. Accounting discretion in fair value estimates: an examination of SFAS 142 goodwill impairments. J. Account. Res. 44(2), 257-287.

Becker, C. L., Defond, M.L., Jiambalvo, J., Subramanyam, K.R., 1998. The effect of audit quality on earnings management. Contemp. Account. Res. 15(1), 1-24.

Bedard, J., Chtourou, S.M., Courteau, L., 2004. The effect of audit committee expertise, independence, and activity on aggressive earnings management. Auditing - J. Pract. Th. $23,15-35$. 
Beekes, W., Brown, P., 2006. Do better-governed Australian firms make more informative disclosures? J. Bus. Finan. Account. 33, 422-450.

Blokdijk, H., Drieenhuizen, F., Simunic, D.A., Stein, M.T., 2006. An analysis of cross-sectional differences in big and non-big public accounting firms' audit programs. Auditing - J. Pract. Th. 25(1), 27-48.

Bradbury, M., Godfrey, J.M., Koh, P.S., 2003. Investment opportunity set influence on goodwill amortization. Asia-Pacific J. Account. Econ. 10(1), 57-79.

Brown, P., Beekes, W., Verhoeven, P., 2011. Corporate governance, accounting and finance: a review. Account. Finan. 51, 96-172.

Cadbury Report, 1992. Report of the Committee on the Financial Aspects of Corporate Governance (Gee, London). Available at http://www.icaew.com/ /media/corporate/files/library/subjects/corporate\%20gove rnance/financial\%20aspects\%20of\%20corporate\%20governance.ashx $\quad$ (accessed 27 December 2013).

Carlin, T.M., Finch, N., Ford, G., 2007. Goodwill impairment - an assessment of disclosure quality and compliance levels by large listed Australian firms. Available at: http://ssrn.com/abstract=963078 (accessed 21 March 2011).

Carlin, T.M., Finch, N., 2008. Goodwill impairment testing under IFRS - a false impossible shore? Available at SSRN: http://ssrn.com/abstract=1173382

Carlin, T.M., Finch, N., 2009. Discount rates in disarray: evidence on flawed goodwill impairment testing. Australian Account. Rev. 19(4), 326-336.

Cerbioni, F., Parbonetti, A., 2007. Exploring the effects of corporate governance on intellectual capital disclosure: an analysis of European biotechnology companies. Eur. Account. Rev. $16,791-826$.

Chalmers, K.G., Godfrey, J.M., Webster, J.C., 2011. Does a goodwill impairment regime better reflect the underlying economic attributes of goodwill? Account. Finan. 51, 634-660.

Chen, C., Kohlbeck, M., Warfield, T., 2004. Goodwill valuation effects of the initial adoption of SFAS 142. Working Paper, University of Wisconsin.

Cheng, E.C.M., Courtenay, S., 2006. Board composition, regulatory regime and voluntary disclosure. Int. J. Account. 41, 262-289.

Dechow, P.M., Sloan, R.G., Sweeney, A.P., 1996. Causes and consequences of earnings manipulation: An analysis of firms subject to enforcement actions by the SEC. Contemp. Account. Res. 13(1), 1-36.

DeZoort, F., Salterio, S., 2001. The effects of corporate governance experience and financial reporting and audit knowledge on audit committee members' judgments. Auditing - J. Pract. Th. 20(2), 31-47. 
Duh, R.-R., Lee, W.-C., Lin, C.-C., 2009. Reversing an impairment loss and earnings management: the role of corporate governance. Int. J. Account. 44, 113-137.

Elliott, J., Hanna, D., 1996. Repeated accounting write-offs and the information content of earnings. J. Account. Res. (Supplement 1996): 135-55.

Eng, L.L., Mak, Y.T., 2003. Corporate governance and voluntary disclosure. J. Account. Public Pol. $22,325-345$.

Fédération des Experts Comptables Européens (FEE), 2001. Enforcement mechanisms in Europe - a preliminary investigation of oversight systems. Available from: http://www.fee.be/images/

publications/accounting/Enforcement\%20Mechanisms\%20in\%20Europe1532005209 52.pdf (accessed 10 June 2008).

Fédération des Experts Comptables Européens (FEE), 2002. Discussion paper on enforcement of IFRS within Europe. Available from: http://www.fee.be/fileupload/ upload/DP\%20on\%20

Enforcement\%20of\%20IFRS\%20within\%20Europe\%20020416320058118.pdf

(accessed 10 June 2008).

Fields, T., Lys, T., Vincent, L., 2001. Empirical research on accounting choice. J. Account. Econ. 31, 255-307.

Francis, J., Hanna, D., Vincent, L., 1996. Causes and effects of discretionary asset write-offs. J. Account. Res. 34, 117-134.

Francis, J. R., Maydew, E.L., Sparks, H.C., 1999. The role of Big 6 auditors in the credible reporting of accruals. Auditing - J. Pract. Th. 18(2), 17-34.

Francis, J.R., Wang, D., 2008. The joint effect of investor protection and big 4 audits on earnings quality around the world. Contemp. Account. Res. 25(1), 157-91.

Godfrey, J.M., Koh, P.S., 2009. Goodwill impairment as a reflection of investment opportunities. Account. Finan. 49, 117-140.

Henning, S.L., Shaw, W.H., Stock, T., 2004. The amount and timing of goodwill write-offs and revaluations: Evidence from the U.S. and U.K. firms. Rev. Quant. Finan. Account. 23, 99121.

International Federation of Accountants (IFAC), 2012. International Standard on Auditing 200 Overall Objectives of the Independent Auditor and the Conduct of an Audit in accordance with International Standards on Auditing. Available at http://www.ifac.org/system/files/publications/files/2012\%20IAASB $\% 20$ Handbook\%2 0Part\%20I Web.pdf (accessed 10 July 2015)

Kalbers, L., Fogarty, T., 1993. Audit committee effectiveness: an empirical investigation of the contribution of power. Auditing - J. Pract. Th. 12(1), 24-49.

Kent, P., J. Stewart, 2008. Corporate governance and disclosures on the transition to international financial reporting standards. Account. Finan. 48, 649-671. 
Kim, J.-B., Chung, R., Firth, M., 2003. Auditor conservatism, asymmetric monitoring and earnings management. Contemp. Account. Res. 20, 323-359.

Klein, A., 2002. Audit committee, board of director characteristics, and earnings management. J. Account. Econ. 33, 375-400.

KPMG, 2014. Who cares about goodwill impairment? A collection of stakeholder views. Available at http://www.kpmg.com/CN/en/IssuesAndInsights/ArticlesPublications/Documents/W ho-cares-about-goodwill-impairment-0-201404.pdf (accessed 2 September 2014).

La Porta, R., Lopez-de-Silanes, F., Shleifer, A., Vishny, R.W., 1998. Law and finance. J. Polit. Econ. $106,1113-1155$.

Lee, P., Stokes, D., Taylor, S., Walter, T., 2003. The association audit quality, accounting disclosures, and firm-specific risk: evidence from initial public offerings. J. Account. Public Pol. 22, 377-400.

Li, Z., Shroff, P., Venkataraman, R., Zhang, I.X., 2010. Causes and consequences of goodwill impairment losses. Available at SSRN: http://ssrn.com/abstract=590908 or http://dx.doi.org/10.2139/ssrn.590908 (accessed on January 10, 1012).

Loh, A.L.C., Tan, T.H., 2002. Asset write-offs - managerial incentives and macroeconomic factors. Abacus 38, 134-151.

McMullen, D., Raghunandan, K., 1996. Enhancing audit committee effectiveness. J. Account. 182 (2), 79-81.

Myers, L., 2001. On the association between governance and control mechanisms and incomedecreasing earnings management. Working paper, University of Michigan.

National Commission on Fraudulent Financial Reporting, 1987. Report of the National Commission on Fraudulent Financial Reporting. Available at http://www.coso.org/Publications/NCFFR.pdf (accessed 5 July 2015).

Nelson, M., Elliott, J., Tarpley, R., 2003. How are earnings managed? Examples from auditors. Account. Horiz. 17 (Supplement):17-35.

Osma, B. G., 2008. Board independence and real earnings management: the case of R\&D expenditure. Corp. Gov. 16: 116-131.

Peasnell, K.V., Pope, P.F., Young, S., 2005. Board monitoring and earnings management: do outside director's influence abnormal accruals? J. Bus. Finan. Account. 32(7), 1311-1346.

Perfect, S.B., Wiles, K.W. 1994. Alternative constructions of Tobin's q: An empirical comparison. J. Emp. Finan. 313-341.

Pope, P.F., McLeay, S.J., 2011. The European IFRS experiment: objectives, research challenges and some early evidence. Account. Bus. Res. 41(3), 233-266.

Pourciau, S., 1993. Earnings management and nonroutine executive changes. J. Account. Econ. 16 (Jan./April/July), 317-336. 
Raghunandan, K., Read, W., Rama, D., 2001. Audit committee composition, "gray directors," and interaction with internal auditing. Account. Horiz. 15(2), 105-118.

Ramanna, K., Watts, R., 2010. Evidence on the use of unverifiable estimates in required goodwill impairment. Harvard Business School Working Paper No. 09-106, available at http://ssrn.com/abstract=1134943 (accessed January 14, 2012).

Riedl, E. J., 2004. An examination of long-lived asset impairments. Account. Rev. 79 (3), 823-852.

Rosenbaum P.R., \& Rubin D.B., (1983), 'The central role of the propensity score in observational studies for causal effects', Biometrika, Vol. 70, pp. 41-55.

Rosenbaum P.R., \& Rubin D.B., (1985), 'Constructing a control group using multivariate matched sampling methods that incorporate the propensity score', The American Statistician, Vol. 39, pp. 33-38.

Scarbrough, D., Rama, D., Raghunandan, K., 1998. Audit committee composition and interaction with internal auditing: Canadian evidence. Account. Horiz. 12(1), 51-62.

Sharma, V.D., 2004. Board of director characteristics, institutional ownership, and fraud: evidence from Australia. Auditing - J. Pract. Th. 23, 105-117.

Sunder, S., 1997. Theory of Accounting and Control. Cincinnati, Ohio: South-Western College Publishing.

United States Securities and Exchange Commission (US SEC), 2000. International Accounting Standards, SEC Concepts Release. Available at http://www.sec.gov/rules/concept/3442430.htm (accessed 15 September 2009).

Walker, M. 2013. How far can we trust earnings numbers? What research tells us about earnings management. Account. Bus. Res. 43 (4), 445-481.

Watts, R.L., Zimmerman, J.L., 1986. Positive Accounting Theory. Englewood Cliffs, NJ: Prentice Hall.

Xie, B., Davidson, W.N., DaDalt, P.J., 2003. Earnings management and corporate governance: the role of the board and the audit committee. J. Corp. Finan. 9 (3), 295-316.

Zhang, I., Zhang, Y., 2007. Accounting discretion and purchase price allocation after acquisitions. Available at http://ssrn.com/abstract=930725 (accessed 10 September 2012). 


\section{Table 1}

Sample

\begin{tabular}{|c|c|c|c|}
\hline \multicolumn{3}{|l|}{ Panel A: Final sample } & Observations \\
\hline \multicolumn{3}{|l|}{ Initial sample with goodwill } & 1960 \\
\hline \multirow{2}{*}{\multicolumn{3}{|c|}{ Less negative book value of equity }} & $\underline{34}$ \\
\hline & & & 1926 \\
\hline \multicolumn{3}{|l|}{ Less no data on model variables } & 143 \\
\hline \multicolumn{3}{|l|}{ Final sample } & $\overline{1783}$ \\
\hline \multicolumn{3}{|l|}{ No goodwill impairment firm-years } & $\overline{1412}$ \\
\hline \multicolumn{3}{|l|}{ Goodwill impairment firm-years } & $\underline{371}$ \\
\hline \multicolumn{3}{|l|}{ Final sample } & $\underline{\underline{1783}}$ \\
\hline \multicolumn{4}{|l|}{ Panel B: Sample by years } \\
\hline 2008 & 2009 & 2012 & Total \\
\hline No. of observations & 327 & 335 & 1783 \\
\hline
\end{tabular}

Panel C: Sample by industry

Aerospace \& defence

Alternative energy

Automobiles \& parts

Beverages

Chemicals

Construction \& materials

Electrical \& electronic equipment

Electricity

Fixed line telecommunications

Food \& drug retailers

Food products

Forestry \& paper

Gas, water \& multiutilities $\quad 16$

General industry $\quad 32$

General retailers $\quad 115$

$\begin{array}{ll}\text { Healthcare equipment \& services } & 79\end{array}$

Household goods \& home construction $\quad 32$

$\begin{array}{ll}\text { Industrial engineering } & 51\end{array}$

$\begin{array}{ll}\text { Industrial goods } & 24\end{array}$

$\begin{array}{ll}\text { Industrial metals \& mining } & 31\end{array}$

$\begin{array}{ll}\text { Industrial transportation } & 39\end{array}$

$\begin{array}{ll}\text { Media } & 97 \\ \end{array}$

$\begin{array}{ll}\text { Mining } & 73\end{array}$

$\begin{array}{ll}\text { Mobile telecommunications } & 27\end{array}$

Oil \& gas products $\quad 16$

Oil equipment \& services $\quad 19$

$\begin{array}{ll}\text { Personal goods } & 31\end{array}$

$\begin{array}{ll}\text { Pharmaceuticals \& biotechnology } & 42\end{array}$

$\begin{array}{ll}\text { Real estate investment trust } & 37\end{array}$

Real estate investments \& services $r 5$

Software \& computer services $\quad 166$

$\begin{array}{lr}\text { Support services } & 228\end{array}$

$\begin{array}{lr}\text { Technology equipment \& services } & 28\end{array}$

Travel \& leisure $\quad \underline{104}$

Total $\quad \underline{1783}$


Table 2

Descriptive statistics

\begin{tabular}{|c|c|c|c|c|c|c|}
\hline \multirow[b]{2}{*}{ Variables } & \multicolumn{2}{|c|}{$\begin{array}{c}\text { DIMPR }_{\mathrm{i}, \mathrm{t}}=1 \\
\mathrm{n}=371\end{array}$} & \multicolumn{2}{|c|}{$\begin{array}{c}\text { DIMPR }_{\mathrm{i}, \mathrm{t}}=0 \\
\mathrm{n}=1412\end{array}$} & \multirow[b]{2}{*}{ t-statistic } & \multirow[b]{2}{*}{$\begin{array}{c}\text { Wilcoxon } \\
\text { statistic }\end{array}$} \\
\hline & Mean & Median & Mean & Median & & \\
\hline$\Delta$ SALES $_{\mathrm{i}, \mathrm{t}}$ & 1.226 & 0.007 & 3.065 & 0.114 & -0.441 & $8.050^{* * *}$ \\
\hline$\Delta \mathrm{CFO}_{\mathrm{i}, \mathrm{t}}$ & 0.013 & -0.004 & 0.023 & 0.012 & -0.629 & $4.129^{* * *}$ \\
\hline DPREIN $_{\mathrm{i}, \mathrm{t}}$ & 0.496 & & 0.803 & & $-12.499 * * *$ & \\
\hline$\Delta \mathrm{INDRO}_{\mathrm{k}, \mathrm{t}}$ & -0.008 & -0.003 & 0.003 & -0.001 & $-2.756^{* * *}$ & $1.761^{*}$ \\
\hline $\mathrm{B} / \mathrm{M}_{\mathrm{i}, \mathrm{t}}$ & 1.388 & 1.007 & 0.968 & 0.667 & $6.098^{* * *}$ & $7.405^{* * *}$ \\
\hline $\mathrm{GDPR}_{\mathrm{t}}$ & 2.606 & 2.433 & 2.828 & 2.433 & $-4.486^{* * *}$ & $4.744^{* * *}$ \\
\hline $\operatorname{DIMPR}_{\mathrm{i}, \mathrm{t}-1}$ & 0.350 & & 0.127 & & $10.426^{* * *}$ & \\
\hline $\mathrm{LEV}_{\mathrm{i}, \mathrm{t}}$ & 0.495 & 0.495 & 0.447 & 0.451 & $4.312^{* * *}$ & $4.158^{* * *}$ \\
\hline $\mathrm{SIZE}_{\mathrm{i}, \mathrm{t}}$ & 12.157 & 12.003 & 12.033 & 12.861 & 1.019 & 0.829 \\
\hline CEOFT $_{\mathrm{i}, \mathrm{t}}$ & 0.221 & & 0.162 & & $2.662^{* * *}$ & \\
\hline CEOLT $_{\mathrm{i}, \mathrm{t}}$ & 0.291 & & 0.147 & & $6.528^{* * *}$ & \\
\hline $\mathrm{SEG}_{\mathrm{i}, \mathrm{t}}$ & 1.059 & 1.099 & 0.865 & 0.693 & $6.049^{* * *}$ & $6.015^{* * *}$ \\
\hline $\mathrm{GI}_{\mathrm{i}, \mathrm{t}}$ & 3.933 & 4.000 & 3.773 & 4.000 & $1.969 * *$ & $1.981^{* *}$ \\
\hline
\end{tabular}

***,** and $*$ denote significance at $<0.01,<0.05$ and $<0.10$ levels (2-tailed), respectively.

Variable definitions:

DIMPR $_{\mathrm{i}, \mathrm{t}}=1$ if firm i reports goodwill impairment loss in year $t$ and 0 otherwise,

$\triangle \mathrm{SALES}_{\mathrm{i}, \mathrm{t}}=$ change in sales of firm $\mathrm{i}$ in year $\mathrm{t}$ divided by year $\mathrm{t}-1$ sales,

$\Delta C F O_{i, t}=$ change in cash flow from operation of firm i in year $t$ divided by total assets at the end of year $t$,

DPREIN $_{\mathrm{i}, \mathrm{t}}=1$ if pre-impairment income (calculated as pre-tax profit plus impairment loss) of firm $\mathrm{i}$ in year $\mathrm{t}$ is positive and 0 otherwise,

$\triangle \mathrm{INDRO}_{\mathrm{k}, \mathrm{t}}=$ change in median return on assets of industry $\mathrm{k}$ in year $\mathrm{t}$,

$\mathrm{B} / \mathrm{M}_{\mathrm{i}, \mathrm{t}}=$ book-to-market ratio of firm $\mathrm{i}$ in year $\mathrm{t}$,

$\mathrm{GDPR}_{\mathrm{t}}=$ gross domestic product growth rate in year $\mathrm{t}$,

DIMPR $_{\mathrm{i}, \mathrm{t}-\mathrm{1}}=1$ if goodwill impairment loss of firm i in year $\mathrm{t}-1$ is positive and 0 otherwise,

$\mathrm{LEV}_{\mathrm{i}, \mathrm{t}}=$ total liabilities divided by total assets of firm $i$ at the end of year $\mathrm{t}$,

$\mathrm{SIZE}_{\mathrm{i}, \mathrm{t}}=$ natural $\log$ of total assets of firm $\mathrm{i}$ at the end of year $\mathrm{t}$,

$\mathrm{CEOFT}_{\mathrm{i}, \mathrm{t}}=1$ if year $\mathrm{t}$ was the first year of the CEO and 0 otherwise,

$\mathrm{CEOLT}_{\mathrm{i}, \mathrm{t}}=1$ if year $\mathrm{t}$ was the last year of the chief executive officer (CEO) and 0 otherwise;

$\mathrm{SEG}_{\mathrm{i}, \mathrm{t}}=$ natural log of the number of segments of firm $\mathrm{i}$ in year $\mathrm{t}$, and

$\mathrm{GI}_{\mathrm{i}, \mathrm{t}}=$ score of the governance index of firm $\mathrm{i}$ in year $\mathrm{t}$. 
Table 3

\begin{tabular}{|c|c|c|c|c|c|c|c|c|c|c|c|c|}
\hline Variables & $\Delta$ SALES $_{\mathrm{i}, \mathrm{t}}$ & $\Delta \mathrm{CFO}_{\mathrm{i}, \mathrm{t}}$ & DPREIN $_{\mathrm{i}, \mathrm{t}}$ & $\Delta \mathrm{INDRO}_{\mathrm{k}, \mathrm{t}}$ & $\mathrm{B} / \mathrm{M}_{\mathrm{i}, \mathrm{t}}$ & GDPR $_{\mathrm{t}}$ & DIMPR $_{\mathrm{i}, \mathrm{t}-1}$ & $\mathrm{LEV}_{\mathrm{i}, \mathrm{t}}$ & SIZE $_{\mathrm{i}, \mathrm{t}}$ & CEOFT $_{\mathrm{i}, \mathrm{t}}$ & CEOLT $_{\mathrm{i}, \mathrm{t}}$ & SEG \\
\hline$\Delta$ SALES $_{\mathrm{i}, \mathrm{t}}$ & 1.000 & & & & & & & & & & & \\
\hline$\Delta \mathrm{CFO}_{\mathrm{i}, \mathrm{t}}$ & $0.339^{* * *}$ & 1.000 & & & & & & & & & & \\
\hline DPREIN $_{\mathrm{i}, \mathrm{t}}$ & -0.001 & 0.032 & 1.000 & & & & & & & & & \\
\hline$\Delta \mathrm{INDRO}_{\mathrm{k}, \mathrm{t}}$ & 0.004 & $-0.042^{*}$ & 0.034 & 1.000 & & & & & & & & \\
\hline $\mathrm{B} / \mathrm{M}_{\mathrm{i}, \mathrm{t}}$ & -0.004 & -0.027 & $-0.170^{* * *}$ & -0.009 & 1.000 & & & & & & & \\
\hline $\mathrm{GDPR}_{\mathrm{t}}$ & 0.028 & 0.004 & $0.099^{* * *}$ & $0.061^{* *}$ & $-0.172^{* * *}$ & 1.000 & & & & & & \\
\hline DIMPR $_{\mathrm{i}, \mathrm{t}-1}$ & -0.015 & 0.006 & $-0.113^{* * *}$ & 0.008 & $0.069^{* * *}$ & $-0.071^{* * *}$ & 1.000 & & & & & \\
\hline $\mathrm{LEV}_{\mathrm{i}, \mathrm{t}}$ & -0.009 & -0.016 & 0.004 & -0.036 & $0.089^{* * *}$ & 0.003 & $0.077^{* * *}$ & 1.000 & & & & \\
\hline SIZE $_{\mathrm{i}, \mathrm{t}}$ & -0.025 & $-0.057^{* *}$ & $0.364^{* * *}$ & -0.007 & $-0.060 * *$ & 0.026 & 0.016 & $0.290 * * *$ & 1.000 & & & \\
\hline CEOFT $_{i, t}$ & -0.002 & $-0.053^{* *}$ & $-0.193^{* * *}$ & -0.006 & $0.052^{* *}$ & 0.005 & 0.032 & 0.025 & $-0.069^{* * *}$ & 1.000 & & \\
\hline CEOLT $_{\mathrm{i}, \mathrm{t}}$ & $0.058^{* *}$ & -0.012 & $-0.131 * * *$ & 0.027 & $0.061^{* *}$ & -0.003 & 0.032 & 0.029 & $-0.067^{* * *}$ & $0.065^{* * *}$ & 1.000 & \\
\hline$S E G_{i, t}$ & -0.014 & -0.013 & $0.053^{* *}$ & -0.001 & -0.017 & $-0.050^{* *}$ & $0.159^{* * *}$ & $0.088^{* * *}$ & $0.430^{* * *}$ & -0.034 & -0.001 & 1.000 \\
\hline VIF & 1.140 & 1.160 & 1.440 & 1.140 & 1.240 & 2.040 & 1.110 & 1.280 & 2.050 & 1.080 & 1.060 & 1.380 \\
\hline
\end{tabular}

$* * *, * *$ and $*$ denote significance at $<0.01,<0.05$ and $<0.10$ levels (2-tailed), respectively. Variables are defined as in Table 2. 
Table 4

Results of regression analysis

\begin{tabular}{|c|c|c|c|c|c|c|}
\hline \multirow[b]{2}{*}{ Variable } & \multicolumn{3}{|c|}{$\begin{array}{c}\text { Model }(1) \\
\text { Dependent Variable }=\text { DIMPR }_{\mathrm{i}, \mathrm{t}}\end{array}$} & \multicolumn{3}{|c|}{$\begin{array}{c}\text { Model }(2) \\
\text { Dependent Variable }=\mathrm{IMPR}_{\mathrm{i}, \mathrm{t}}\end{array}$} \\
\hline & Full sample & $\mathrm{DGI}=1$ & $\mathrm{DGI}=0$ & Full sample & $\mathrm{DGI}=1$ & $\mathrm{DGI}=0$ \\
\hline \multirow[t]{2}{*}{$\mathrm{C}$} & 0.422 & 3.451 & -1.103 & 0.517 & 0.625 & -0.220 \\
\hline & $(0.150)$ & $(0.850)$ & $(-0.230)$ & $(0.690)$ & $\left(2.530^{* *}\right)$ & $(-0.120)$ \\
\hline \multirow[t]{2}{*}{$\Delta \mathrm{SALES}_{\mathrm{i}, \mathrm{t}}$} & -0.000 & -0.368 & -0.000 & -0.001 & -0.005 & -0.001 \\
\hline & $(-0.530)$ & $\left(-2.230^{* *}\right)$ & $(-0.610)$ & $\left(-2.040^{* *}\right)$ & $(-0.860)$ & $(-1.430)$ \\
\hline \multirow[t]{2}{*}{$\Delta \mathrm{CFO}_{\mathrm{i}, \mathrm{t}}$} & 0.077 & -1.036 & 0.184 & 0.661 & -0.144 & 0.796 \\
\hline & $(0.210)$ & $\left(-1.710^{*}\right)$ & $(0.690)$ & $\left(12.880^{* * *}\right)$ & $\left(-3.630^{* * *}\right)$ & $\left(9.520^{* * *}\right)$ \\
\hline \multirow[t]{2}{*}{ DPREIN $_{\mathrm{i}, \mathrm{t}}$} & -1.496 & -1.524 & -1.302 & -0.344 & -0.091 & -0.448 \\
\hline & $\left(-8.810^{* * *}\right)$ & $\left(-6.170^{* * *}\right)$ & $\left(-4.820^{* * *}\right)$ & $\left(-7.790^{* * *}\right)$ & $(-6.270 * * *)$ & $(-4.300 * * *)$ \\
\hline \multirow[t]{2}{*}{$\Delta \mathrm{INDRO}_{\mathrm{k}, \mathrm{t}}$} & -1.008 & -0.962 & -0.498 & -0.627 & -0.079 & -1.044 \\
\hline & $(-1.010)$ & $(-0.480)$ & $(-0.320)$ & $\left(-2.550^{* *}\right)$ & $(-0.850)$ & $\left(-1.970^{* *}\right)$ \\
\hline \multirow[t]{2}{*}{$\mathrm{B} / \mathrm{M}_{\mathrm{i}, \mathrm{t}}$} & 0.145 & 0.243 & 0.011 & 0.024 & 0.015 & -0.025 \\
\hline & $\left(2.490^{* *}\right)$ & $\left(1.860^{*}\right)$ & $(0.110)$ & $(1.590)$ & $\left(3.590^{* * *}\right)$ & $(-0.510)$ \\
\hline \multirow[t]{2}{*}{$\mathrm{GDPR}_{\mathrm{t}}$} & -1.088 & -2.102 & -0.380 & -0.347 & -0.204 & -0.188 \\
\hline & $(-1.450)$ & $(-1.860 *)$ & $(-0.300)$ & $\left(-1.740^{*}\right)$ & $\left(-3.080^{* * *}\right)$ & $(-0.380)$ \\
\hline \multirow[t]{2}{*}{ DIMPR $_{\mathrm{i}, \mathrm{t}-1}$} & 0.961 & 0.680 & 1.066 & & & \\
\hline & $\left(6.160^{* * *}\right)$ & $\left(3.320^{* * *}\right)$ & $\left(3.960^{* * *}\right)$ & & & \\
\hline \multirow{2}{*}{$\mathrm{IMPR}_{\mathrm{i}, \mathrm{t}-1}$} & & & & -0.007 & 0.014 & -0.069 \\
\hline & & & & $(-0.150)$ & $(0.730)$ & $(-0.550)$ \\
\hline \multirow[t]{2}{*}{$\mathrm{LEV}_{\mathrm{i}, \mathrm{t}}$} & 0.855 & 1.169 & 0.913 & 0.242 & 0.047 & 0.449 \\
\hline & $\left(2.440^{* *}\right)$ & $\left(2.140^{* *}\right)$ & $\left(1.710^{*}\right)$ & $\left(2.550^{* *}\right)$ & $(1.440)$ & $\left(2.050^{* *}\right)$ \\
\hline \multirow[t]{2}{*}{ SIZE $E_{i, t}$} & 0.102 & 0.087 & 0.078 & 0.002 & -0.005 & -0.006 \\
\hline & $\left(2.560^{* *}\right)$ & $(1.460)$ & $(0.970)$ & $(0.140)$ & $(-1.310)$ & $(-0.190)$ \\
\hline \multirow[t]{2}{*}{ CEOFT $_{i, t}$} & 0.659 & 0.735 & 0.567 & 0.153 & 0.044 & 0.213 \\
\hline & $\left(3.930^{* * *}\right)$ & $\left(3.090^{* * *}\right)$ & $\left(2.080^{* *}\right)$ & $\left(3.650^{* * *}\right)$ & $\left(3.260^{* * *}\right)$ & $\left(2.070^{* *}\right)$ \\
\hline \multirow[t]{2}{*}{ CEOLT $_{i, t}$} & 0.110 & 0.108 & 0.097 & 0.041 & 0.010 & 0.061 \\
\hline & $(0.640)$ & $(0.420)$ & $(0.360)$ & $(0.920)$ & $(0.700)$ & $(0.580)$ \\
\hline \multirow[t]{2}{*}{$\mathrm{SEG}_{\mathrm{i}, \mathrm{t}}$} & 0.565 & 0.761 & 0.387 & 0.157 & 0.044 & 0.172 \\
\hline & $\left(3.980^{* * *}\right)$ & $\left(4.180^{* * *}\right)$ & $(1.540)$ & $\left(4.140^{* * *}\right)$ & $\left(3.540^{* * *}\right)$ & $\left(1.870^{*}\right)$ \\
\hline INDUSTRY & Included & Included & Included & Included & Included & Included \\
\hline YEAR & Included & Included & Included & Included & Included & Included \\
\hline $\mathrm{N}$ & 1783 & $1089^{1}$ & $673^{2}$ & 1783 & 1096 & 687 \\
\hline $\begin{array}{l}\text { Log } \\
\text { (pseudo)lik } \\
\text { elihood }\end{array}$ & -732.744 & -427.627 & -267.958 & -641.346 & -72.693 & -291.873 \\
\hline Pseudo R ${ }^{2}$ & 0.196 & 0.235 & 0.209 & 0.220 & 0.631 & 0.229 \\
\hline
\end{tabular}

$* * *, * *$ and ${ }^{*}$ denote significance at $<0.01,<0.05$ and $<0.10$ levels (2-tailed), respectively. Figures in parentheses are $\mathrm{z}$ statistics. DGI is 1 if the value of the governance index of the firm is at least equal to the median and 0 otherwise. IMPR $\mathrm{i}_{\mathrm{i}-\mathrm{-}-\mathrm{is}}$ isoodwill impairment loss of firm $\mathrm{i}$ in year $\mathrm{t}-1$ divided by total assets at the end of year $\mathrm{t}-2$. Other variables are as defined in Table 2. Z statistics for model (1) variables are based on robust standard errors clustered by firms. Log pseudolikelihood and log likelihood statistics are for logit and tobit regressions, respectively.

${ }^{1}$ Stata did not use seven (7) observations in running this logit regression.

2Stata did not use 14 observations in running this logit regression. 
Table 5

Impact of individual components of corporate governance on associations between economic factors and contracting incentives and goodwill impairment

Panel A: Model (1) Dependent Variable is DIMPR

\begin{tabular}{|c|c|c|c|c|c|c|c|c|c|c|c|c|}
\hline \multirow[t]{2}{*}{ Variable } & \multicolumn{2}{|c|}{ Board Independence } & \multicolumn{2}{|c|}{$\begin{array}{l}\text { Audit Committee } \\
\text { Independence }\end{array}$} & \multicolumn{2}{|c|}{ Big 4 Auditor } & \multicolumn{2}{|c|}{$\begin{array}{l}\text { Audit Committee } \\
\text { Expertise }\end{array}$} & \multicolumn{2}{|c|}{$\begin{array}{l}\text { Audit Committee Meeting } \\
\text { Frequency }\end{array}$} & \multicolumn{2}{|c|}{ CEO Separation } \\
\hline & $\mathrm{BIND}=1$ & BIND $=0$ & ACIND $=1$ & ACIND $=0$ & BIG4=1 & BIG4=0 & ACEXP $=1$ & ACEXP $=0$ & ACMEET $=1$ & ACMEET $=0$ & CEOSEP $=1$ & CEOSEP $=0$ \\
\hline $\mathrm{C}$ & $\begin{array}{c}-3.621 \\
(-0.830)\end{array}$ & $\begin{array}{c}4.811 \\
(1.230)\end{array}$ & $\begin{array}{l}-1.893 \\
(-0.610)\end{array}$ & $\begin{array}{c}8.569 \\
(1.070)\end{array}$ & $\begin{array}{c}2.976 \\
(0.820)\end{array}$ & $\begin{array}{c}-5.451 \\
(-0.940)\end{array}$ & $\begin{array}{l}-0.008 \\
(-0.000)\end{array}$ & $\begin{array}{c}1.763 \\
(0.330)\end{array}$ & $\begin{array}{c}7.070 \\
(1.210)\end{array}$ & $\begin{array}{l}-0.897 \\
(-0.260)\end{array}$ & $\begin{array}{c}1.508 \\
(0.530)\end{array}$ & $\begin{array}{l}-27.543 \\
\left(-2.380^{* *}\right)\end{array}$ \\
\hline$\Delta$ SALES $_{\mathrm{i}, \mathrm{t}}$ & $\begin{array}{l}0.022 \\
\left(2.210^{* *}\right)\end{array}$ & $\begin{array}{l}-0.001 \\
(-0.480)\end{array}$ & $\begin{array}{c}0.007 \\
(1.250)\end{array}$ & $\begin{array}{l}-0.002 \\
(-0.930)\end{array}$ & $\begin{array}{l}-0.015 \\
(-0.410)\end{array}$ & $\begin{array}{l}-0.000 \\
(-0.550)\end{array}$ & $\begin{array}{l}-0.003 \\
(-0.530)\end{array}$ & $\begin{array}{c}0.007 \\
(1.160)\end{array}$ & $\begin{array}{l}-0.204 \\
(-1.150)\end{array}$ & $\begin{array}{l}-0.000 \\
(-0.440)\end{array}$ & $\begin{array}{l}-0.000 \\
(-0.400)\end{array}$ & $\begin{array}{l}-0.161 \\
\left(-2.370^{* *}\right)\end{array}$ \\
\hline$\Delta \mathrm{CFO}_{\mathrm{i}, \mathrm{t}}$ & $\begin{array}{l}-1.244 \\
\left(-1.980^{* *}\right)\end{array}$ & $\begin{array}{c}0.210 \\
(0.940)\end{array}$ & $\begin{array}{l}-1.253 \\
\left(-2.740^{* * *}\right)\end{array}$ & $\begin{array}{l}0.414 \\
\left(2.240^{* *}\right)\end{array}$ & $\begin{array}{l}-0.649 \\
(-1.080)\end{array}$ & $\begin{array}{c}0.229 \\
(0.870)\end{array}$ & $\begin{array}{l}-1.300 \\
\left(-2.480^{* *}\right)\end{array}$ & $\begin{array}{c}0.293 \\
(1.550)\end{array}$ & $\begin{array}{l}-0.211 \\
(-0.210)\end{array}$ & $\begin{array}{c}0.071 \\
(0.220)\end{array}$ & $\begin{array}{c}0.094 \\
(0.260)\end{array}$ & $\begin{array}{c}1.114 \\
(0.680)\end{array}$ \\
\hline DPREIN $_{\mathrm{i}, \mathrm{t}}$ & $\begin{array}{l}-2.048 \\
\left(-7.350^{* * *}\right)\end{array}$ & $\begin{array}{l}-1.182 \\
\left(-5.480^{* * *}\right)\end{array}$ & $\begin{array}{l}-1.570 \\
\left(-7.840^{* * *}\right)\end{array}$ & $\begin{array}{l}-1.520 \\
\left(-4.040^{* * *}\right)\end{array}$ & $\begin{array}{l}-1.454 \\
\left(-6.360^{* * *}\right)\end{array}$ & $\begin{array}{l}-1.614 \\
\left(-5.060^{* * *}\right)\end{array}$ & $\begin{array}{l}-1.397 \\
\left(-7.020^{* * *}\right)\end{array}$ & $\begin{array}{l}-1.999 \\
\left(-6.100^{* * *}\right)\end{array}$ & $\begin{array}{l}-1.589 \\
\left(-4.370^{* * *}\right)\end{array}$ & $\begin{array}{l}-1.474 \\
\left(-6.770^{* * *}\right)\end{array}$ & $\begin{array}{l}-1.526 \\
\left(-8.480^{* * *}\right)\end{array}$ & $\begin{array}{c}-1.259 \\
\left(-1.700^{*}\right)\end{array}$ \\
\hline$\Delta \mathrm{INDRO}_{\mathrm{k}, \mathrm{t}}$ & $\begin{array}{l}-0.418 \\
(-0.170)\end{array}$ & $\begin{array}{l}-1.445 \\
(-1.170)\end{array}$ & $\begin{array}{l}-0.249 \\
(-0.240)\end{array}$ & $\begin{array}{c}-2.858 \\
(-1.330)\end{array}$ & $\begin{array}{c}-1.994 \\
\left(-1.710^{*}\right)\end{array}$ & $\begin{array}{c}1.358 \\
(0.720)\end{array}$ & $\begin{array}{l}-1.291 \\
(-1.050)\end{array}$ & $\begin{array}{l}-0.740 \\
(-0.440)\end{array}$ & $\begin{array}{c}1.275 \\
(0.360)\end{array}$ & $\begin{array}{l}-0.820 \\
(-0.690)\end{array}$ & $\begin{array}{l}-1.286 \\
(-1.270)\end{array}$ & $\begin{array}{c}6.156 \\
(1.330)\end{array}$ \\
\hline $\mathrm{B} / \mathrm{M}_{\mathrm{i}, \mathrm{t}}$ & $\begin{array}{c}0.243 \\
\left(1.810^{*}\right)\end{array}$ & $\begin{array}{c}0.074 \\
(1.280)\end{array}$ & $\begin{array}{c}0.173 \\
\left(2.330^{* *}\right)\end{array}$ & $\begin{array}{c}0.070 \\
(0.680)\end{array}$ & $\begin{array}{c}0.210 \\
\left(2.020^{* *}\right)\end{array}$ & $\begin{array}{c}0.048 \\
(0.430)\end{array}$ & $\begin{array}{c}0.159 \\
\left(2.090^{* *}\right)\end{array}$ & $\begin{array}{c}0.082 \\
(0.640)\end{array}$ & $\begin{array}{c}0.650 \\
\left(3.530^{* * *}\right)\end{array}$ & $\begin{array}{c}0.051 \\
(0.950)\end{array}$ & $\begin{array}{c}0.131 \\
\left(2.250^{* *}\right)\end{array}$ & $\begin{array}{c}0.317 \\
(0.700)\end{array}$ \\
\hline $\mathrm{GDPR}_{\mathrm{t}}$ & $\begin{array}{c}-0.125 \\
(-0.110)\end{array}$ & $\begin{array}{l}-2.119 \\
\left(-1.980^{* *}\right)\end{array}$ & $\begin{array}{l}-0.529 \\
(-0.620)\end{array}$ & $\begin{array}{c}-3.351 \\
(-1.540)\end{array}$ & $\begin{array}{l}-1.941 \\
\left(-1.900^{* *}\right)\end{array}$ & $\begin{array}{c}0.484 \\
(0.320)\end{array}$ & $\begin{array}{l}-1.095 \\
(-1.150)\end{array}$ & $\begin{array}{l}-1.370 \\
(-0.930)\end{array}$ & $\begin{array}{l}-3.777 \\
\left(-2.410^{* *}\right)\end{array}$ & $\begin{array}{l}-0.311 \\
(-0.330)\end{array}$ & $\begin{array}{l}-1.420 \\
\left(-1.800^{*}\right)\end{array}$ & $\begin{array}{c}5.669 \\
\left(1.840^{*}\right)\end{array}$ \\
\hline $\mathrm{DIMPR}_{\mathrm{i}, \mathrm{t}-1}$ & $\begin{array}{l}0.842 \\
\left(3.420^{* * *}\right)\end{array}$ & $\begin{array}{c}0.995 \\
\left(4.450^{* * *}\right)\end{array}$ & $\begin{array}{l}1.021 \\
\left(5.500^{* * *}\right)\end{array}$ & $\begin{array}{c}0.564 \\
(1.550)\end{array}$ & $\begin{array}{l}0.782 \\
\left(4.190^{* * *}\right)\end{array}$ & $\begin{array}{l}0.906 \\
\left(3.140^{* * *}\right)\end{array}$ & $\begin{array}{c}0.942 \\
\left(4.830^{* * *}\right)\end{array}$ & $\begin{array}{c}0.760 \\
\left(2.730^{* * *}\right)\end{array}$ & $\begin{array}{c}0.562 \\
\left(1.670^{*}\right)\end{array}$ & $\begin{array}{l}0.971 \\
\left(5.280^{* * *}\right)\end{array}$ & $\begin{array}{l}0.899 \\
\left(5.590^{* * *}\right)\end{array}$ & $\begin{array}{c}1.504 \\
\left(1.700^{*}\right)\end{array}$ \\
\hline $\mathrm{LEV}_{\mathrm{i}, \mathrm{t}}$ & $\begin{array}{c}0.917 \\
(1.490)\end{array}$ & $\begin{array}{c}0.918 \\
\left(2.020^{* *}\right)\end{array}$ & $\begin{array}{c}0.820 \\
\left(1.800^{*}\right)\end{array}$ & $\begin{array}{l}1.877 \\
\left(2.640^{* * *}\right)\end{array}$ & $\begin{array}{c}1.358 \\
\left(2.550^{* *}\right)\end{array}$ & $\begin{array}{c}0.768 \\
(1.440)\end{array}$ & $\begin{array}{c}0.561 \\
(1.260)\end{array}$ & $\begin{array}{c}1.260 \\
(1.610)\end{array}$ & $\begin{array}{c}2.638 \\
\left(3.170^{* * *}\right)\end{array}$ & $\begin{array}{c}0.648 \\
(1.480)\end{array}$ & $\begin{array}{c}0.869 \\
\left(2.300^{* *}\right)\end{array}$ & $\begin{array}{c}2.759 \\
\left(1.680^{*}\right)\end{array}$ \\
\hline SIZE $_{i, t}$ & $\begin{array}{c}0.153 \\
\left(2.410^{* *}\right)\end{array}$ & $\begin{array}{c}0.027 \\
(0.460)\end{array}$ & $\begin{array}{l}0.112 \\
\left(2.510^{* *}\right)\end{array}$ & $\begin{array}{c}0.081 \\
(0.620)\end{array}$ & $\begin{array}{c}0.093 \\
(1.640)\end{array}$ & $\begin{array}{c}0.186 \\
\left(1.720^{*}\right)\end{array}$ & $\begin{array}{l}0.132 \\
\left(2.740^{* * *}\right)\end{array}$ & $\begin{array}{c}0.120 \\
(1.460)\end{array}$ & $\begin{array}{c}0.190 \\
\left(2.120^{* *}\right)\end{array}$ & $\begin{array}{c}0.009 \\
(0.160)\end{array}$ & $\begin{array}{c}0.107 \\
\left(2.530^{* *}\right)\end{array}$ & $\begin{array}{c}0.319 \\
(1.240)\end{array}$ \\
\hline CEOFT $_{\mathrm{i}, \mathrm{t}}$ & $\begin{array}{c}0.696 \\
\left(2.540^{* *}\right)\end{array}$ & $\begin{array}{c}0.586 \\
\left(2.520^{* *}\right)\end{array}$ & $\begin{array}{c}0.748 \\
\left(3.700^{* * *}\right)\end{array}$ & $\begin{array}{c}0.108 \\
(0.320)\end{array}$ & $\begin{array}{l}0.801 \\
\left(3.650^{* * *}\right)\end{array}$ & $\begin{array}{c}0.431 \\
(1.470)\end{array}$ & $\begin{array}{l}0.670 \\
\left(3.240^{* * *}\right)\end{array}$ & $\begin{array}{c}0.425 \\
(1.210)\end{array}$ & $\begin{array}{c}0.367 \\
(1.090)\end{array}$ & $\begin{array}{l}0.773 \\
\left(3.780^{* * *}\right)\end{array}$ & $\begin{array}{l}0.664 \\
\left(3.810^{* * *}\right)\end{array}$ & $\begin{array}{c}1.561 \\
\left(1.730^{*}\right)\end{array}$ \\
\hline CEOLT $_{\mathrm{i}, \mathrm{t}}$ & $\begin{array}{c}0.186 \\
(0.640)\end{array}$ & $\begin{array}{l}-0.072 \\
(-0.300)\end{array}$ & $\begin{array}{c}-0.031 \\
(-0.140)\end{array}$ & $\begin{array}{c}0.327 \\
(0.860)\end{array}$ & $\begin{array}{c}0.011 \\
(0.050)\end{array}$ & $\begin{array}{c}0.288 \\
(1.050)\end{array}$ & $\begin{array}{c}0.026 \\
(0.120)\end{array}$ & $\begin{array}{c}0.553 \\
(1.580)\end{array}$ & $\begin{array}{c}0.409 \\
(1.240)\end{array}$ & $\begin{array}{l}-0.077 \\
(-0.360)\end{array}$ & $\begin{array}{c}0.137 \\
(0.770)\end{array}$ & $\begin{array}{c}-0.144 \\
(-0.100)\end{array}$ \\
\hline SEGi,t & $\begin{array}{l}0.786 \\
\left(3.660^{* * *}\right)\end{array}$ & $\begin{array}{c}0.418 \\
\left(2.110^{* *}\right)\end{array}$ & $\begin{array}{c}0.682 \\
\left(4.140^{* * *}\right)\end{array}$ & $\begin{array}{c}0.397 \\
(1.180)\end{array}$ & $\begin{array}{c}0.649 \\
\left(3.710^{* * *}\right)\end{array}$ & $\begin{array}{c}0.497 \\
\left(1.780^{*}\right)\end{array}$ & $\begin{array}{c}0.514 \\
\left(3.130^{* * *}\right)\end{array}$ & $\begin{array}{c}0.404 \\
(1.140)\end{array}$ & $\begin{array}{c}0.898 \\
\left(3.080^{* * *}\right)\end{array}$ & $\begin{array}{l}0.594 \\
\left(3.270^{* * *}\right)\end{array}$ & $\begin{array}{l}0.537 \\
\left(3.650^{* * *}\right)\end{array}$ & $\begin{array}{c}1.300 \\
(1.600)\end{array}$ \\
\hline INDUSTRY & Included & Included & Included & Included & Included & Included & Included & Included & Included & Included & Included & Included \\
\hline $\begin{array}{l}\text { YEAR } \\
\mathrm{N}\end{array}$ & $\begin{array}{l}\text { Included } \\
774\end{array}$ & $\begin{array}{l}\text { Included } \\
978\end{array}$ & $\begin{array}{l}\text { Included } \\
1382\end{array}$ & $\begin{array}{l}\text { Included } \\
377\end{array}$ & $\begin{array}{l}\text { Included } \\
1136\end{array}$ & $\begin{array}{l}\text { Included } \\
578\end{array}$ & $\begin{array}{l}\text { Included } \\
1277\end{array}$ & $\begin{array}{l}\text { Included } \\
472\end{array}$ & $\begin{array}{l}\text { Included } \\
542\end{array}$ & $\begin{array}{l}\text { Included } \\
1217\end{array}$ & $\begin{array}{l}\text { Included } \\
1627\end{array}$ & $\begin{array}{l}\text { Included } \\
124\end{array}$ \\
\hline $\begin{array}{l}\text { Log } \\
\text { pseudolikel } \\
\text { ihood }\end{array}$ & -310.560 & -391.420 & -553.619 & -148.346 & -472.200 & -227.428 & -516.440 & -188.820 & -206.287 & -479.882 & -674.890 & -41.220 \\
\hline Pseudo R² & 0.260 & 0.190 & 0.208 & 0.280 & 0.206 & 0.243 & 0.213 & 0.234 & 0.322 & 0.195 & 0.200 & 0.366 \\
\hline
\end{tabular}

Panel B: Model (2) Dependent Variable is IMPR $\mathrm{i}_{\mathrm{i}, \mathrm{t}}$ 


\begin{tabular}{|c|c|c|c|c|c|c|c|c|c|c|c|c|}
\hline \multirow[t]{2}{*}{ Variable } & \multicolumn{2}{|c|}{ Board Independence } & \multicolumn{2}{|c|}{$\begin{array}{l}\text { Audit Committee } \\
\text { Independence }\end{array}$} & \multicolumn{2}{|c|}{ Big 4 Auditor } & \multicolumn{2}{|c|}{$\begin{array}{c}\text { Audit Committee } \\
\text { Expertise } \\
\end{array}$} & \multicolumn{2}{|c|}{$\begin{array}{c}\text { Audit Committee Meeting } \\
\text { Frequency }\end{array}$} & \multicolumn{2}{|c|}{ CEO Separation } \\
\hline & BIND=1 & BIND $=0$ & ACIND=1 & ACIND $=0$ & BIG4=1 & BIG4 $=0$ & ACEXP $=1$ & ACEXP $=0$ & ACMEET $=1$ & ACMEET $=0$ & CEOSEP $=1$ & CEOSEP $=0$ \\
\hline $\mathrm{C}$ & $\begin{array}{l}-0.315 \\
(-0.590)\end{array}$ & $\begin{array}{c}2.012 \\
\left(1.650^{*}\right)\end{array}$ & $\begin{array}{l}-0.008 \\
(-0.020)\end{array}$ & $\begin{array}{c}3.249 \\
(1.160)\end{array}$ & $\begin{array}{c}1.115 \\
(1.640)\end{array}$ & $\begin{array}{l}-1.899 \\
(-0.950)\end{array}$ & $\begin{array}{c}0.478 \\
\left(1.770^{*}\right)\end{array}$ & $\begin{array}{c}0.158 \\
(0.060)\end{array}$ & $\begin{array}{c}0.582 \\
\left(1.980^{* *}\right)\end{array}$ & $\begin{array}{c}0.454 \\
(0.400)\end{array}$ & $\begin{array}{c}0.642 \\
(0.800)\end{array}$ & $\begin{array}{c}-0.471 \\
(-0.630)\end{array}$ \\
\hline$\Delta \mathrm{SALES}_{\mathrm{i}, \mathrm{t}}$ & $\begin{array}{c}0.001 \\
(1.110)\end{array}$ & $\begin{array}{l}-0.001 \\
(-1.070)\end{array}$ & $\begin{array}{c}0.001 \\
(0.620)\end{array}$ & $\begin{array}{l}-0.002 \\
(-0.540)\end{array}$ & $\begin{array}{c}0.006 \\
(0.800)\end{array}$ & $\begin{array}{l}-0.010 \\
(-1.570)\end{array}$ & $\begin{array}{l}-0.000 \\
(-0.310)\end{array}$ & $\begin{array}{c}0.001 \\
(0.300)\end{array}$ & $\begin{array}{l}-0.013 \\
(-1.290)\end{array}$ & $\begin{array}{l}-0.001 \\
\left(-1.960^{* *}\right)\end{array}$ & $\begin{array}{l}-0.001 \\
\left(-2.500^{* *}\right)\end{array}$ & $\begin{array}{c}-0.005 \\
(-1.320)\end{array}$ \\
\hline$\Delta \mathrm{CFO}_{\mathrm{i}, \mathrm{t}}$ & $\begin{array}{l}-0.475 \\
\left(-5.770^{* * *}\right)\end{array}$ & $\begin{array}{l}0.807 \\
\left(12.590^{* * *}\right)\end{array}$ & $\begin{array}{l}-0.348 \\
\left(-5.830^{* * *}\right)\end{array}$ & $\begin{array}{l}0.916 \\
\left(10.070^{* * *}\right)\end{array}$ & $\begin{array}{l}0.416 \\
\left(2.930^{* * *}\right)\end{array}$ & $\begin{array}{l}0.714 \\
\left(9.990^{* * *}\right)\end{array}$ & $\begin{array}{l}-0.136 \\
\left(-3.120^{* * *}\right)\end{array}$ & $\begin{array}{l}0.863 \\
\left(9.070^{* * *}\right)\end{array}$ & $\begin{array}{l}-0.006 \\
(-0.120)\end{array}$ & $\begin{array}{l}0.706 \\
\left(10.920^{* * *}\right)\end{array}$ & $\begin{array}{l}0.679 \\
\left(12.690^{* * *}\right)\end{array}$ & $\begin{array}{c}0.089 \\
(0.990)\end{array}$ \\
\hline DPREIN $_{\mathrm{i}, \mathrm{t}}$ & $\begin{array}{l}-0.231 \\
\left(-6.740^{* * *}\right)\end{array}$ & $\begin{array}{l}-0.316 \\
\left(-4.640^{* * *}\right)\end{array}$ & $\begin{array}{l}-0.173 \\
\left(-7.820^{* * *}\right)\end{array}$ & $\begin{array}{l}-0.411 \\
\left(-2.850^{* * *}\right)\end{array}$ & $\begin{array}{l}-0.194 \\
\left(-4.670^{* * *}\right)\end{array}$ & $\begin{array}{l}-0.583 \\
\left(-5.370^{* * *}\right)\end{array}$ & $\begin{array}{l}-0.116 \\
\left(-7.210^{* * *}\right)\end{array}$ & $\begin{array}{l}-0.693 \\
\left(-4.720^{* * *}\right)\end{array}$ & $\begin{array}{l}-0.065 \\
\left(-4.330^{* * *}\right)\end{array}$ & $\begin{array}{l}-0.414 \\
\left(-6.170^{* * *}\right)\end{array}$ & $\begin{array}{l}-0.355 \\
\left(-7.460^{* * *}\right)\end{array}$ & $\begin{array}{c}-0.060 \\
(-1.500)\end{array}$ \\
\hline$\Delta \mathrm{INDRO}_{\mathrm{k}, \mathrm{t}}$ & $\begin{array}{l}-0.368 \\
(-1.520)\end{array}$ & $\begin{array}{l}-0.890 \\
\left(-2.530^{* *}\right)\end{array}$ & $\begin{array}{l}-0.157 \\
(-1.190)\end{array}$ & $\begin{array}{l}-2.313 \\
\left(-2.770^{* * *}\right)\end{array}$ & $\begin{array}{l}-1.020 \\
\left(-4.280^{* * *}\right)\end{array}$ & $\begin{array}{c}0.326 \\
(0.560)\end{array}$ & $\begin{array}{l}-0.120 \\
(-1.120)\end{array}$ & $\begin{array}{l}-1.181 \\
\left(-1.800^{*}\right)\end{array}$ & $\begin{array}{c}0.063 \\
(0.540)\end{array}$ & $\begin{array}{l}-0.707 \\
\left(-2.020^{* *}\right)\end{array}$ & $\begin{array}{l}-0.734 \\
\left(-2.740^{* * *}\right)\end{array}$ & $\begin{array}{c}0.370 \\
\left(1.750^{*}\right)\end{array}$ \\
\hline $\mathrm{B} / \mathrm{M}_{\mathrm{i}, \mathrm{t}}$ & $\begin{array}{c}0.015 \\
(1.250)\end{array}$ & $\begin{array}{c}0.006 \\
(0.270)\end{array}$ & $\begin{array}{c}0.016 \\
\left(2.180^{* *}\right)\end{array}$ & $\begin{array}{c}0.008 \\
(0.140)\end{array}$ & $\begin{array}{l}0.035 \\
\left(2.770^{* * *}\right)\end{array}$ & $\begin{array}{c}-0.031 \\
(-0.640)\end{array}$ & $\begin{array}{l}0.013 \\
\left(2.710^{* * *}\right)\end{array}$ & $\begin{array}{c}-0.007 \\
(-0.110)\end{array}$ & $\begin{array}{l}0.027 \\
\left(4.750^{* * *}\right)\end{array}$ & $\begin{array}{c}0.002 \\
(0.070)\end{array}$ & $\begin{array}{c}0.021 \\
(1.330)\end{array}$ & $\begin{array}{c}-0.009 \\
(-0.470)\end{array}$ \\
\hline $\mathrm{GDPR}_{\mathrm{t}}$ & $\begin{array}{c}0.023 \\
(0.160)\end{array}$ & $\begin{array}{l}-0.759 \\
\left(-2.340^{* *}\right)\end{array}$ & $\begin{array}{l}-0.070 \\
(-0.740)\end{array}$ & $\begin{array}{l}-1.256 \\
\left(-1.670^{*}\right)\end{array}$ & $\begin{array}{l}-0.493 \\
\left(-2.700^{* * *}\right)\end{array}$ & $\begin{array}{c}0.260 \\
(0.490)\end{array}$ & $\begin{array}{l}-0.172 \\
\left(-2.370^{* *}\right)\end{array}$ & $\begin{array}{c}-0.426 \\
(-0.640)\end{array}$ & $\begin{array}{l}-0.209 \\
\left(-2.520^{* *}\right)\end{array}$ & $\begin{array}{l}-0.265 \\
(-0.880)\end{array}$ & $\begin{array}{l}-0.387 \\
\left(-1.810^{*}\right)\end{array}$ & $\begin{array}{c}0.068 \\
(0.340)\end{array}$ \\
\hline IMPR $_{\mathrm{i}, \mathrm{t}-1}$ & $\begin{array}{c}0.071 \\
(0.700)\end{array}$ & $\begin{array}{l}-0.048 \\
(-0.540)\end{array}$ & $\begin{array}{c}0.124 \\
(1.620)\end{array}$ & $\begin{array}{c}-0.137 \\
(-0.730)\end{array}$ & $\begin{array}{c}0.028 \\
(0.510)\end{array}$ & $\begin{array}{c}-0.021 \\
(-0.210)\end{array}$ & $\begin{array}{c}0.008 \\
(0.530)\end{array}$ & $\begin{array}{c}-0.076 \\
(-0.440)\end{array}$ & $\begin{array}{l}0.023 \\
\left(2.220^{* *}\right)\end{array}$ & $\begin{array}{l}-0.019 \\
(-0.240)\end{array}$ & $\begin{array}{l}-0.009 \\
(-0.180)\end{array}$ & $\begin{array}{c}-0.119 \\
(-0.470)\end{array}$ \\
\hline $\mathrm{LEV}_{\mathrm{i}, \mathrm{t}}$ & $\begin{array}{c}0.018 \\
(0.240)\end{array}$ & $\begin{array}{l}0.432 \\
\left(2.950^{* * *}\right)\end{array}$ & $\begin{array}{c}0.041 \\
(0.810)\end{array}$ & $\begin{array}{l}0.830 \\
\left(2.940^{* * *}\right)\end{array}$ & $\begin{array}{c}0.389 \\
\left(3.960^{* * *}\right)\end{array}$ & $\begin{array}{c}0.099 \\
(0.490)\end{array}$ & $\begin{array}{c}0.057 \\
(1.620)\end{array}$ & $\begin{array}{l}0.656 \\
\left(2.170^{* *}\right)\end{array}$ & $\begin{array}{l}0.116 \\
\left(3.280^{* * *}\right)\end{array}$ & $\begin{array}{c}0.268 \\
\left(1.930^{*}\right)\end{array}$ & $\begin{array}{c}0.253 \\
\left(2.490^{* *}\right)\end{array}$ & $\begin{array}{c}0.018 \\
(0.190)\end{array}$ \\
\hline SIZE $_{i, t}$ & $\begin{array}{c}0.005 \\
(0.560)\end{array}$ & $\begin{array}{l}-0.029 \\
(-1.470)\end{array}$ & $\begin{array}{c}0.004 \\
(0.590)\end{array}$ & $\begin{array}{c}-0.017 \\
(-0.310)\end{array}$ & $\begin{array}{l}-0.003 \\
(-0.300)\end{array}$ & $\begin{array}{c}0.025 \\
(0.690)\end{array}$ & $\begin{array}{l}-0.003 \\
(-0.760)\end{array}$ & $\begin{array}{c}0.018 \\
(0.460)\end{array}$ & $\begin{array}{l}-0.001 \\
(-0.140)\end{array}$ & $\begin{array}{l}-0.026 \\
(-1.380)\end{array}$ & $\begin{array}{c}0.002 \\
(0.120)\end{array}$ & $\begin{array}{c}0.011 \\
(0.680)\end{array}$ \\
\hline CEOFT $_{i, t}$ & $\begin{array}{c}0.033 \\
(1.060)\end{array}$ & $\begin{array}{l}0.175 \\
\left(2.580^{* * *}\right)\end{array}$ & $\begin{array}{c}0.052 \\
\left(2.450^{* *}\right)\end{array}$ & $\begin{array}{c}0.087 \\
(0.640)\end{array}$ & $\begin{array}{l}0.107 \\
\left(2.720^{* * *}\right)\end{array}$ & $\begin{array}{c}0.192 \\
\left(1.980^{* *}\right)\end{array}$ & $\begin{array}{l}0.050 \\
\left(3.280^{* * *}\right)\end{array}$ & $\begin{array}{c}0.132 \\
(0.940)\end{array}$ & $\begin{array}{c}0.023 \\
\left(1.700^{*}\right)\end{array}$ & $\begin{array}{l}0.246 \\
\left(3.850^{* * *}\right)\end{array}$ & $\begin{array}{c}0.159 \\
\left(3.570^{* * *}\right)\end{array}$ & $\begin{array}{c}0.069 \\
(1.370)\end{array}$ \\
\hline CEOLT $_{\mathrm{i}, \mathrm{t}}$ & $\begin{array}{c}0.004 \\
(0.130)\end{array}$ & $\begin{array}{l}-0.013 \\
(-0.180)\end{array}$ & $\begin{array}{l}-0.007 \\
(-0.310)\end{array}$ & $\begin{array}{c}0.112 \\
(0.820)\end{array}$ & $\begin{array}{c}0.002 \\
(0.040)\end{array}$ & $\begin{array}{c}0.079 \\
(0.780)\end{array}$ & $\begin{array}{l}-0.009 \\
(-0.540)\end{array}$ & $\begin{array}{c}0.234 \\
\left(1.670^{*}\right)\end{array}$ & $\begin{array}{l}0.029 \\
\left(2.010^{* *}\right)\end{array}$ & $\begin{array}{c}0.006 \\
(0.090)\end{array}$ & $\begin{array}{c}0.043 \\
(0.910)\end{array}$ & $\begin{array}{c}0.036 \\
(0.700)\end{array}$ \\
\hline$S E G_{i, t}$ & $\begin{array}{l}0.079 \\
\left(2.580^{* * *}\right)\end{array}$ & $\begin{array}{l}0.169 \\
\left(2.900^{* * *}\right)\end{array}$ & $\begin{array}{c}0.063 \\
\left(3.290^{* * *}\right)\end{array}$ & $\begin{array}{c}0.169 \\
(1.330)\end{array}$ & $\begin{array}{c}0.112 \\
\left(3.000^{* * *}\right)\end{array}$ & $\begin{array}{c}0.161 \\
\left(1.850^{*}\right)\end{array}$ & $\begin{array}{l}0.038 \\
\left(2.820^{* * *}\right)\end{array}$ & $\begin{array}{c}0.158 \\
(1.120)\end{array}$ & $\begin{array}{l}0.027 \\
\left(2.020^{* *}\right)\end{array}$ & $\begin{array}{l}0.207 \\
\left(3.570^{* * *}\right)\end{array}$ & $\begin{array}{l}0.154 \\
\left(3.810^{* * *}\right)\end{array}$ & $\begin{array}{c}0.076 \\
\left(1.810^{*}\right)\end{array}$ \\
\hline $\begin{array}{l}\text { INDUSTR } \\
\mathrm{Y}\end{array}$ & Included & Included & Included & Included & Included & Included & Included & Included & Included & Included & Included & Included \\
\hline YEAR & Included & Included & Included & Included & Included & Included & Included & Included & Included & Included & Included & Included \\
\hline $\mathrm{N}$ & 782 & 1001 & 1388 & 395 & 1144 & 639 & 1286 & 497 & 560 & 1223 & 1627 & 156 \\
\hline $\begin{array}{l}\text { Log } \\
\text { likelihood }\end{array}$ & -148.088 & -365.858 & -253.622 & -173.533 & -336.098 & -237.497 & -157.532 & -217.285 & 18.346 & -460.779 & -599.485 & 2.109 \\
\hline $\begin{array}{l}\text { Pseudo } \\
\mathrm{R}^{2}\end{array}$ & 0.384 & 0.260 & 0.312 & 0.317 & 0.221 & 0.290 & 0.455 & 0.259 & 1.252 & 0.221 & 0.221 & 1.065 \\
\hline
\end{tabular}

***, $* *$ and $*$ denote significance at $<0.01,<0.05$ and $<0.10$ levels (2-tailed), respectively. Figures in parentheses are $\mathrm{z}$ statistics. $\mathrm{Z}$ statistics for model (1) variables in Panel A are based on robust standard errors clustered by firms. The total number of observations for two sub-samples for a particular governance attribute (e.g., board independence, audit committee independence, Big 4 auditor, audit committee expertise, audit committee meeting frequency and CEO separation) 
should be 1783. This holds good for tobit regressions in Panel B but not for logit regressions in Panel A. This is because Stata logit command drops observations when the model is underidentified.

Where

BIND $=1$ if two-thirds of the board members are independent, 0 otherwise.

ACIND $=1$ if two-thirds of the members of the audit committee are independent, 0 otherwise.

BIG4 = 1 if the firm-year observation has a Big 4 auditor, 0 otherwise.

ACEXP $=1$ if at least one member of the audit committee is a qualified accountant, 0 otherwise.

ACMEET $=1$ if the frequency of the audit committee meeting is above the sample median, 0 otherwise.

CEOSEP $=1$ if the posts of the chairman and the CEO are held by separate persons, 0 otherwise.

Other variables are as defined in Tables 2 and 4. 
Table 6

Pre-impairment income and goodwill impairment loss

\begin{tabular}{|c|c|c|c|c|c|c|}
\hline Variable & \multicolumn{6}{|c|}{ Panel A: Negative pre-im } \\
\hline Vailavie & \multicolumn{2}{|c|}{$\begin{array}{c}\operatorname{DIMPR}_{\mathrm{i}, \mathrm{t}}=1 \\
(\mathrm{n}=187)\end{array}$} & \multicolumn{2}{|c|}{$\begin{array}{c}\text { DIMPR }_{\mathrm{i}, \mathrm{t}}=0 \\
(\mathrm{n}=278)\end{array}$} & \multirow{2}{*}{$\begin{array}{l}\text { t-statistic } \\
\text { for difference } \\
\text { in means }\end{array}$} & \multirow{2}{*}{$\begin{array}{l}\text { Wilcoxon } \\
\text { statistic for } \\
\text { difference in } \\
\text { medians }\end{array}$} \\
\hline \multirow[b]{2}{*}{ ROA } & Mean & Median & Mean & Median & & \\
\hline & -0.508 & -0.226 & -0.193 & -0.099 & $5.490^{* * *}$ & $6.049^{* * *}$ \\
\hline \multicolumn{7}{|c|}{ Panel B: Goodwill impairment loss sample } \\
\hline \multirow[t]{2}{*}{ Variable } & \multicolumn{2}{|c|}{$\begin{array}{c}\text { DPREIN }_{\mathrm{i}, \mathrm{t}}=1 \\
(\mathrm{n}=184)\end{array}$} & \multicolumn{2}{|c|}{$\begin{array}{c}\text { DPREIN }_{\mathrm{i}, \mathrm{t}}=0 \\
(\mathrm{n}=187)\end{array}$} & \multirow{2}{*}{$\begin{array}{l}\text { t-statistic } \\
\text { for difference } \\
\text { in means }\end{array}$} & \multirow{2}{*}{$\begin{array}{l}\text { Wilcoxon } \\
\text { statistic for } \\
\text { difference in } \\
\text { medians }\end{array}$} \\
\hline & Mean & Median & Mean & Median & & \\
\hline ROA & 0.013 & 0.026 & -0.508 & -0.226 & $-7.761^{* * *}$ & $14.036^{* * *}$ \\
\hline
\end{tabular}

DIMPR $_{i, t}=1$ if firm i reports goodwill impairment loss in year $t$ and 0 otherwise,

DPREIN $_{\mathrm{i}, \mathrm{t}}=1$ if pre-impairment loss income (calculated as pre-tax profit plus impairment loss) of firm $\mathrm{i}$ in year $t$ is positive and 0 otherwise

ROA = net income divided by total assets 